\title{
Organizing Language Interpreting Services in Elderly and Emergency Healthcare
}

\author{
Christina Lundin
}

\author{
Division of Nursing Science \\ Department of Social and Welfare Studies \\ Linköping University, Sweden \\ Linköping 2018
}

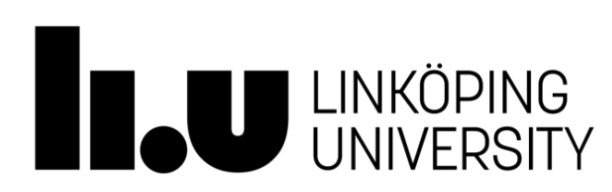


(C)Christina Lundin, 2018

Cover/picture/Illustration/Design: Christina Lundin

Published article has been reprinted with the permission of the copyright holder.

Printed in Sweden by LiU-Tryck, Linköping, Sweden, 2018

ISBN 978-91-7685-366-5

ISSN 1100-6013 
With love to my family and my newborn grandchild Tuva

ORD

Ett ord som en människa fäster sig vid kan verka i oberäknelig tid.

Det kan framkalla glädje till livets slut, det kan uppväcka obehag i livet ut.

Ja, det påverkar livet på jorden.

Så slarva inte med orden!

A word that a person might fasten upon can have an effect for a very long time.

It may arouse joy for the rest of your life, it may be a permanent cause of distress.

A word can affect all of life upon earth. So mind what you say, please be careful with words!

Alf Henrikson 1905-1995 



\section{CONTENTS}

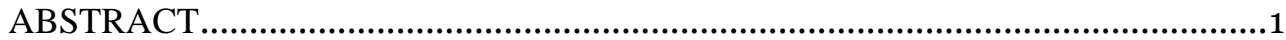

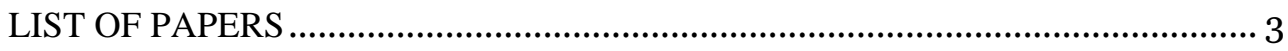

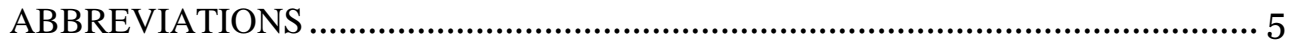

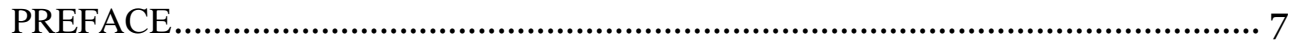

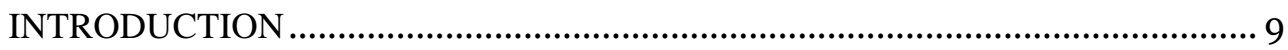

Organization of interpreting services in Sweden ................................................ 11

Language barriers and interpreting practices in healthcare ...................................13

Language barriers and communication in emergency and elderly healthcare ...........................................................................................13

Language interpreting practices in healthcare ...............................................14

Theoretical framework ………………..........................................................16

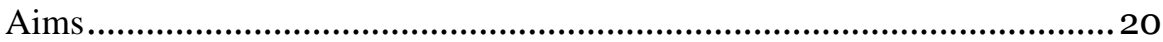

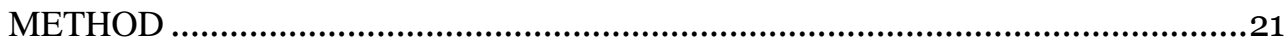

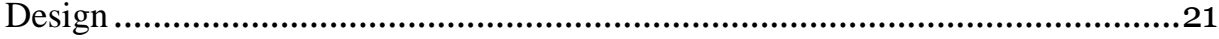

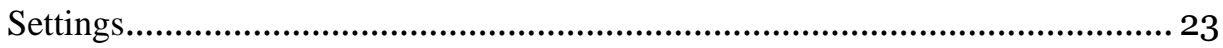

Participants and procedures ............................................................................ 23

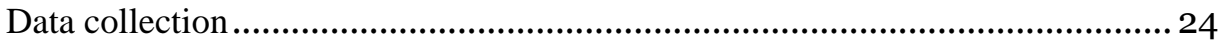

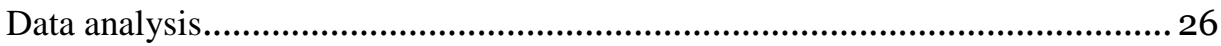

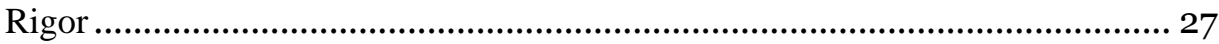

Ethical considerations ................................................................................... 29

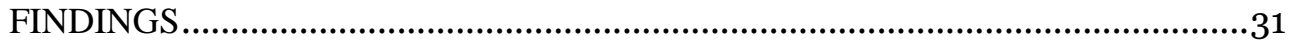

Organization of interpreting services regulated by healthcare professionals, based on informal guidelines with varying knowledge of national laws .............. 32 Healthcare professionals' perceptions and experiences of interpreter use and organizing interpreting practices

The characteristic of the care given and the person's needs and health situation as determining factor for interpreter use

Professionals' proposals for improving the organization of interpreting practices

DISCUSSION ……....................................................................................

CONCLUSIONS …...........................................................................................

SVENSK SAMMANFATTNING ……………………..................................... 53 


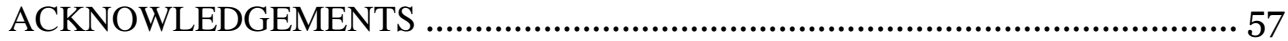

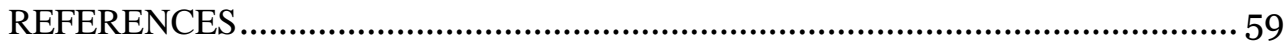




\section{ABSTRACT}

With an increasing migrant population there is a growing need to organize interpreting practices in healthcare in order to deliver equitable high-quality care.

This thesis focuses on healthcare institutions' organization of interpreting services. The aim of the study was to explore interpreting practices in a healthcare context by comparing two different healthcare areas - elderly and emergency healthcare. The study aimed to highlight the impact of the organizational and institutional context.

This study was designed as an explorative and descriptive qualitative study including 79 healthcare professionals with experience of interpreting practices recruited via purposeful sampling in elderly and emergency healthcare. Data were collected through individual and focus-group interviews and analysed with inductive qualitative content analysis.

The main findings show that the processes and structures around interpreting practices were complex and mainly linked to individual and interpersonal levels and, to a limited extent, to the institutional level. On the institutional level the Public Procurement Act was the only formal policy to follow. On individual and interpersonal level interpreting practices were structured by self-established informal workplace routines developed by the professional groups. The norms and routines used was determined by access to interpreters, time aspects, characteristics of the care given, health conditions and the person's problem, expectations and requests from the person and also from healthcare professionals. There were wishes for improvement, with better flexibility in access to professional interpreters, training for users and interpreters, and also better technical solutions and equipment.

In conclusion, the use of interpreters was rooted in the organizational environment of interpreting practice, including the availability of laws, policy and guidelines, and closely related to individuals' language skills, cultural values and social factors. The use of professional interpreters was based on the nature of care in context and access to interpreters and determined by health professionals' estimation of the person's current health status in order to deliver fast and individualized care based on humanistic values. 
Thus, it is important to consider organizational framework and cultural awareness when formulating interpreting practices adapted to the context, and formal guidelines in order to achieve the aim of personcentered and equal health care

Keywords: Communication, Emergency healthcare, Elderly healthcare, Interpreting practices, Organizing, Qualitative methods, Transcultural nursing. 


\section{LIST OF PAPERS}

I. Hadziabdic E, Lundin C, Hjelm K. Boundaries and conditions of interpretation in multilingual and multicultural elderly healthcare. BMC Health Services Research 2015: 15:458. DOI 10. 1186/s12913015-1124-5

II. Lundin C, Hadziabdic E, Hjelm K. Language interpretation conditions and boundaries in multilingual and multicultural emergency healthcare, 2017. Submitted manuscript. 


\section{ABBREVIATIONS}

MYH Swedish National Agency for Higher Vocational Education

SCB Statistics Sweden

SFS Swedish Code of Statutes

SOU Official Reports of the Swedish Government

SNBHW Swedish National Board of Health and Welfare

WHO World Health Organization 


\section{PREFACE}

Language interpreting has existed ever since people with different languages met. An important role in relationships between people using professional interpreters started at the International Labour Conference in Geneva, Switzerland in 1927, when simultaneous interpreting was used for the very first time. The year 1946 saw the start of interpreting in a large scale during the Nuremberg war crimes trial, and shortly after the trial ended, in 1947, the United Nations Resolution established simultaneous interpreting as a permanent service for the United Nations (Delisle \& Woodworth 2012). In Sweden, as in other countries, community interpreting has developed since the 1960 s and is still very much in a development process, although professional interpreting training has been in existence since 1968 (Niska 2007).

In my work as a healthcare professional, since 1982, I have experienced the importance of communication as a central part in care situations. To meet and care for patients unable to understand each other because of different languages complicates the care that was intended to be provided. During my working period different ways to achieve communication were used when language barriers occurred, ways based on habits in the professional group. Sometimes body language was used without knowing the outcome of the communication, and sometimes professional interpreters were used in special circumstances. The choice of which language support to use (or no support) was made without any education or training about language barriers, or any thoughts or discussions with colleagues about the consequence for the care of the patients or the consequences for us as professionals.

My intention with this thesis is to view language interpreting practices from the perspective of healthcare professionals, how they arrange the interpreting practices and how the actions performed impact the care. The ambition is to contribute to the field of care in connection with interpreting practices by obtaining increased understanding and knowledge from the experiences of healthcare professionals. 


\section{INTRODUCTION}

Globally the migrant population has increased in recent years and around 244 million international migrants are moving around in the world (International Organization for Migration, IOM 2017). In Sweden, 17\% of the population were born in another country (Statistics Sweden, SCB 2016) and Sweden is a multilingual society with around 150 spoken languages (Inst. Språk och folkminnen 2017). Since the migrant population has increased (SCB 2016) it has become an important issue for healthcare professionals in Sweden to provide and organize health care and elderly care for people with culturally and linguistically diverse backgrounds. Janson and Wadensjö (2014) argue that since Sweden has become more multilingual, care institutions need to realize the need handle interpreting issues as a complex linguistic, communicative and social practice. Healthcare institutions need to manage language-adapted care and interpreting services in order to offer equal healthcare conditions, since the use of language and communication is essential to promote people's well-being and health (Leininger \& McFarland 2006). World Health Organization. (WHO 2008) state that humans has basic rights and freedom to access quality healthcare, and that individuals should be treated fairly, equally and impartially.

Previous research about language interpreting practices in healthcare in general has been limited to the migrant, healthcare professional and interpreter perspectives. The area of communication through interpreters in healthcare has been investigated from a migrant point of view (Edwards et al. 2005; MacFarlane et al. 2009; Fatahi et al. 2010 a) and from healthcare staff perspective (Gerrish \& Clayton 2004, Fatahi et al. 2008; Rosenberg et al. 2008; Fatahi, et al. 2010 b; Brämberg \& Sandman 2013). Furthermore, the use of interpreters in healthcare has been investigated from a migrant perspective (Hadziabdic et al. 2009; Ramsey et al. 2012; Hadziabdic et al. 2014; Hadziabdic \& Hjelm 2014; Krupic et al. 2016) and from a healthcare staff perspective (Hadziabdic et al. 2010; Krupic et al. 2017). There have also been studies identifying problems when using interpreter in healthcare (Hadziabdic et al. 2011; Krupic et al. 2016) and investigating factors influencing the provider's choice of interpreter (Hsieh 2015). Studies have been found regarding the interpreter's role and behaviour during healthcare encounters (Leanza 2005; Hsieh 2008; Hsieh \& Kramer 2012; Hadziabdic \& Hjelm 2016). 
No previous studies have been found investigating interpreting practices in healthcare by comparing two different areas, elderly and emergency healthcare, and the impact of the organizational and institutional context. Thus, there is a lack of knowledge concerning how healthcare professionals organize interpreting practices in elderly and emergency healthcare from an organizational perspective.

Elderly and emergency healthcare are two health contexts that differ in both the goals and the character of the care practices performed, and they can be seen as a contrast to each other. Eldercare in Sweden is regulated by the Social Services Act (SFS 2001:453) and the Health and Medical Services Act (SFS 2017:30), regulations ensuring a person's social right to assistance and care when dependent on care. The process of need and placement in eldercare is carried out by a care manager and is not income-based (Szebehely \& Trydegård 2012). The goal for eldercare is to establish such conditions that the elderly can grow old in security, can maintain independence and live an active life and have influence in the community in their everyday life (Ministry of Health and Social Affairs, Prop. 2009/10:116 2017). The characteristic of eldercare concerns wellplanned activities performed in longstanding contact consistent with a variety of everyday life activities as well as complex healthcare. Eldercare can consist of help with household tasks, personal care and emotional and/or social support in home care services or nursing homes for people over 65 years of age. Home care services are assistance in the form of service and personal care in the individual residence or equivalent, or 24hour care in a nursing home. These apply often to the most ill elderly with multiple disorders and requiring a lot of help with needs, many times during day and night (Szebehely \& Trydegård 2012; Official Reports of the Swedish Government, SOU 2017:21). To enable elderly migrants to participate in everyday life when needing language-adapted care in elderly healthcare, the provision of language-congruent care using professionals speaking the language of the care recipient is mentioned as a solution in different reports from Swedish National Board of Health and Welfare (SNBHW 2015; 2016 a; 2016 b).

Emergency healthcare can consist of prehospital interventions in ambulance service, ranging from life-sustaining measures to advanced emergency care or just transportation to hospital and somatic or psychiatric emergency departments with the aim of resolving the acute problems or referring the patient to the appropriate health care provider. The goal for emergency health care institutions is to carry out emergency assessments, to give telephone advice and consultancy around the clock. 
The characteristic of the care in emergency units is a care with high intensity, short encounters, unknown people, unscheduled assessments or interventions (Reilly \& Markenson 2010).

Care delivered in the psychiatric emergency unit or psychiatric intensive care units is mainly focused on acute measures connected to severe dysfunction of mood, behaviour, perception, or thoughts that might be a threat to life (Brenner et al. 2016). Somatic and psychiatric emergency healthcare are specialized healthcare form with the overall purpose being to stabilize the emergency situation (Reilly \& Markenson 2010; Brenner et al. 2016).

\section{Organization of interpreting services in Sweden}

In Sweden the main legal framework for interpreting practices consists of the Public Management Act (SFS 1986:223). It is a regulatory law requiring healthcare professionals to use interpreters in health care situations where language barriers occur. This law states the right to an interpreter in contact with public authorities and gives healthcare professionals the right to decide when a person shows a lack of understanding and should have an interpreter. The law does not imply the right for healthcare professionals to use an interpreter in order to do their work as professionals. Nor is there any law that regulates the degree of educational level of the interpreter used in healthcare in Sweden.

The legal framework also contains other laws that can be used in decisions about communication and interpreting practices, such as the Health and Medical Services Act (SFS 2017:30) the Patient Act (SFS 2014:821) and the Social Services Act (SFS 2001:453), which state that care institutions must provide for all inhabitants to achieve good health and a feeling of well-being on equal terms and with respect for self-determination and human dignity. The law states that the information given should be adapted to the person, considering age, maturity, experiences and language background, and given in such a way that participation is promoted. To act according to this mission, healthcare institutions need to organize good communication for all inhabitants regardless of the language spoken.

To guarantee the quality of language interpreting service, institutions in the public service sector should use contracted interpreting agencies according to the Public Procurement Act (SFS 2016:1145). 
This is a system that should guarantee agencies the best price for the best quality. The system provides healthcare professionals with guidelines and specific instructions about which agency to use and how to contact an interpreter.

The agencies used are run by public service or private enterprises outside the healthcare institutions. Some agencies are linked to professional organizations such as the Interpreter Services Council with its own guidelines for "good interpreter services practice" to guarantee good quality (SNBHW 2016). In Sweden there are two state-financed education agencies training interpreter education: the National Agency for Higher Vocational Education (MYH) and the Institute for Interpreting and Translation Studies (TÖI). The interpreters provided can have different qualifications and the majority of the active interpreters are neither trained nor authorized (Almqvist 2016). An interpreter can work as a consecutive interpreter translating between people by dialogue, where the interpreter first listens and then translates into the other language word by word and then in the reverse direction. The interpreter can also work on place or at a distance through different technical solutions (SNBHW 2016 c).

In Sweden, authorization for qualified interpreters with the best quality has been regulated since 1985 in order to set and maintain high national standards in the fields of translation and interpreting (SFS 1985:613). Authorized interpreters qualified by the Legal, Financial and Administrative Services Agency in Sweden (Kammarkollegiet) have passed a knowledge test that covers language competence skills in interpreting techniques and civics, or interpreters who have a basic education without authorization (SNBHW 2016 c). Authorized interpreters follow guidelines about translating word by word and behave neutrally and professionally, maintaining secrecy and integrity (Kammarkollegiet 2017). Currently there is not only an overall lack of interpreters in Sweden but also a lack of similar and formalized education for interpreters (MYH 2015). 


\section{Language barriers and interpreting practices in healthcare}

\section{Language barriers and communication in emergency and elderly healthcare}

Misunderstandings because of limited communication are an increasing hindrance to accessing healthcare (Bischoff 2003), and language barriers have shown to be a risk factor concerning migrant people's health and are mentioned by migrant patients as the major problem in contact with healthcare (Seffo et al. 2014). Earlier studies in somatic emergency healthcare have shown how language barriers increase risk of misdiagnosis (Hampers et al. 1999), lead to limited access to diagnoses, diagnostic testing and treatment (Ramirez et al. 2008; Ventriglio et al. 2014;) as well as longer stay for the patients at the emergency department (Mahmoud et al. 2013; Njeru et al. 2015). In psychiatric emergency healthcare, Bauer and Alegria (2010) found that errors by untrained interpreters affected healthcare professionals' ability to understand patients' disordered thoughts or delusional content.

The use of professional interpreters in emergency healthcare promotes the best quality of communication and increase patient satisfaction (Ramirez et al. 2008; Bagchi et al. 2011), it also leads to better services and reduces return rates (Bernstein 2002). However, professional interpreters are underutilized in emergency healthcare context (Ramirez et al. 2008; Ginde et al. 2009; Ginde et al. 2010), one reason could be the use of friends and family members as interpreters, which many patients were comfortable with (Ginde et al. 2010).

In elderly healthcare previous studies concerning language interpreting are limited. One study of the interpreter's role in an elderly homecare context showed that an interpreter needs to be present, with face-to-face interpreting to take a more active part in elderly care, explaining medical terms and other concepts when needed (Brämberg \& Sandman 2013).

In health encounters it is of special importance for healthcare professionals to have access to good communication with possibilities to talk about the outcome of the person's migration process, since previous studies show that the migration process can have affected their health (Albin et al. 2005; Syse et al. 2016; Wallace \& Kulu 2014). 


\section{Language interpreting practices in healthcare}

Previous studies have shown that insufficient communication is a risk to patient safety (Divi et al. 2007) and also increases the costs for health care (Jacobs et al. 2011). Language barriers have an impact on both the patient and the healthcare system, creating health inequalities (Akhavan 2002; Liu et al. 2015). Research has shown that the use of professional interpreters is the best way to achieve good communication quality when language barriers hinder communication (Flores 2005; Karliner et al. 2007). Both patients and healthcare professionals are generally positive about using professional interpreters, but the degree of accessibility to professional interpreters varies and is often limited in relation to the need (Fatahi et al. 2008; Fatahi et al. 2010; Kale et al. 2010; Karliner et al. 2011; Krupic et al 2017). Instead, informal ad hoc interpreters such as family members or bilingual staff are commonly used by healthcare professionals in different health areas (Gerrish \& Clayton 2004; Bischoff \& Hudelson 2010).

Healthcare professionals state that the behaviour, attitude and appearance of the interpreter can affect the healthcare situation (Hadziabdic et al. 2009; Krupic et al. 2017). The role of the interpreter can also be extended to a role as mediator and a bridge between cultures (Rosenberg et al. 2008; Messias et al. 2009). Professionals state that the alliance of providers and interpreter also supports the patient's emotional needs (Hsieh \& Hong 2010) and the interpreter's behaviour and the alliance between providers and interpreter are critical to the success of the interpreting situation (Hsieh 2008; Krupic et al. 2016).

From the interpreter's perspective, they viewed their role to be about translating and transferring correctly, being objective and maintaining confidentiality in interpreting situations. They experience their role in line with existing guidelines for interpreters (Hadziabdic \& Hjelm 2016). Another study about the interpreter's role found that interpreters say that their role could be more active, including their emotions and interpersonal relationships which could be used as instruments to accomplish the healthcare professionals' goals (Hsieh \& Kramer 2012). Some interpreters saw themselves merely as a transceiver of information, while others saw their role in wider terms, as patient advocacy, cultural brokerage and facilitating emotional support (Butow et al. 2012). Interpreters describe their work role as complex and challenging and that also went beyond linguistic transformation (McDowell et al. 2011). 
Patients in need of interpreters raise problems with experiences of interpreters being late, lacking professionalism or lacking a knowledge of medical terminology (Krupic et al. 2016). Patients also have experiences of that use of interpreters are overall more common in contact with physicians than in contact with nurses (Schenker et al 2011). Other difficulties in the interpreting situation are also linked to the balance between trust, control and power between the actors involved and institutional recognition of the interpreter's role (Brisset et al. 2013). Previous research with patients about interpreting situations shows that the feeling of trust and safety for the patient is emphasized by the involvement of their family members as interpreter (Edwards et al. 2005; Hadziabdic et al. 2014). Family members were preferred as interpreters since they also could interpret latent content and contribute cultural knowledge which helped explain the intended message (Rosenberg et al. 2008). In contrast, other studies have shown that patients have better trust in professional interpreters because of neutrality and correct translation (Hadziabdic et al 2009; MacFarlane et al 2009). To use family members as interpreters was not always positive for the family member because of mixed emotions since they had to give both practical and emotional support while acting in the role of interpreter (Hadziabdic et al. 2014).

Other aspects such as non-functional equipment, disrespect for appointments, lack of documentation of the language/dialect spoken by the patient and availability of interpreters as well as access to an interpreter agency can negatively affect the healthcare situation (Hadziabdic et al. 2010).

Research about how language interpreting practices are organized in healthcare is limited. One study in hospital care argue that the organizing of interpreters is a complex issue, influenced by and depending on both therapeutic and ethical factors, such as lack of time, disruption in the scheduled care and overburdening at the unit. The study found that both interpersonal aspects and organizational aspects affect the decision for healthcare professionals in the routines for the use of interpreters (Hsieh 2015). Another study of organizational disadvantages in primary healthcare showed that most problems were related to organizational issues or to interpreters' limited language competence (Hadziabdic et al. 2011). 
In sum, previous research of interpreting practices has been done with healthcare professionals, interpreters and patients, around experiences of communication with interpreters, use of interpreters, and problems associated with interpreting have been identified, as well as factors influencing the choice of different types of interpreter. Studies have also been carried out regarding the role and skills of the interpreter, type of interpreter used, technical equipment and the interpreting in conjunction with the healthcare meeting. However less is known about how interpreting services are organized in different healthcare contexts. Therefore healthcare professionals' experience of interpreting practices and routines are important to study in order to improve communication situations and provide an organized interpreting service of high quality that contributes to equitable healthcare for the increased population in Sweden who need language-adapted healthcare.

\section{Theoretical framework}

This study is mainly based on theories of transcultural care (Leininger \& McFarland 2006; Ray 2016), language and communication (Linell 2011) and organizations and routines (Greenhalgh et al. 2007; Feldman \& Pentland 2003; Ray \& Turkel 2015), to understand how the healthcare performed is in relation to the organization and the importance of routines.

From a care perspective transcultural nursing emphasizes the need to provide care based on the individual's cultural beliefs, practices and values. It has its origins in an understanding of humanism with the main aim of caring as promoting or regaining health and well-being (Leininger $\&$ McFarland 2006). Transcultural nursing includes cultural competence, a competence that is aimed to improve healthcare quality by healthcare professionals understanding and managing sociocultural variations in the health beliefs and behaviours of the patient. Cultural competence is described as a strategy to increase health equity by facilitating decisions and actions performed by healthcare professionals, in order to contribute to individualized care on equal terms and to promote high-quality communication (Leininger \& McFarland 2006; Ray 2016). Cultural competence skills are described as having awareness, sensitivity and transcultural knowledge to give culturally congruent care by turning to the cultural needs of the person (Leininger \& McFarland 2006). 
The transcultural approach focuses not only on the person's cultural values, but also stresses the need to include the cultural understanding built into the healthcare institutions as well as the cultural background of the individual healthcare professional, in order to provide cultural congruent healthcare (Leininger \& McFarland 2006; Kirmayer 2011).

Care is described as a complex and relational concept that relies on the interaction between individuals and others in their lifeworld (Ray 2016). In transcultural nursing care communication and interaction are core factors of care, and the outcome of healthcare is determined by the possibilities to communicate with good quality (Leininger \& McFarland 2006; Ray 2016). Healthcare professionals are legally responsible to generate the most accurate data possible in healthcare encounters with patients who do not speak the language of the healthcare professional (Ray 2016). To develop good interaction and create meaningful meetings with the person in need of care can be a lifesaving aspect for health and patient safety as well as the quality of care (Leininger \& McFarland 2006; Ray 2016).

When creating meaningful communication it is important to take into account that there is a unique tie between language and culture as embodied in the individual and the culture at the same time (Leininger \& McFarland 2006; Linell 2011; Ray 2016). Ray describes culture as something assigned with humanity, society and civilization, including structural elements in society and as dynamic processes that change over time in relation to different conditions and circumstances, on both individual and social level (Ray 2016). A person's culture is tied to language and by language individuals regulate social life, express feelings and organize experiences. Language provides us with the words and concepts to describe the world around us and language also includes body language such as gestures and voice tone (Linell 2005). Communication and language are described by Linell (2011) as a multifaceted phenomenon where humans transfer deliberate and conscious information, with ability to perceive knowledge, abstract concepts, thoughts, ideas and symbols and to transfer it to others and also to themselves. Through communication the person's identity is made visible and also shows how the other person is perceived. Humans need language to build up their life and to live their everyday life. Human societies and cultures are built by those who live in them by shared communication, and by our concepts and world-wide perceptions that are produced by communicative structures (Linell 2011). 
From an intersectional perspective of ethnicity it is important to understand the need for an objective view of people, not only on a cultural basis but also on the basis of class, socio-economy, gender, age, sexuality and education in order to prevent the creation of differences between people. To use an objective view from different perspectives can prevent migrant people from falling into racial and/or ethnic groups from being excluded as "others" in need of special arrangements (Engstrand \& Larsson 2013). The way healthcare professionals discuss and reason about language interpretation and the way care recipients can participate in communication situations in healthcare institutions contributes to the field of ethnicity on the societal level (Lill 2007). To participate in society and health situations, individuals also need legal and health literacy including a certain ability to understand, assess, access and communicate selected information about the care obtained, confronting social injustice in order to achieve health and well-being (Vissandjée et al. 2017).

Communication in relation to an institutional context is of interest since the conversation differs from everyday conversations in the way that the professional is a socially recognized and sanctioned expert who performs certain tasks with access to formalized routines. The conversation is more functional oriented, with a subject and purpose often decided in advance, and the turn taking in the conversation is more regulated than in everyday conversation. The relation of power and control between patients and professionals need to be handled carefully since the two parties do not have the same agendas, knowledge or resources (Linell 1990; 2011). Communication performed in the institution is linked to the routinizing of action and praxis by professionals (Linell 1990). In conversations within institutional settings it is crucial, for participation, how the conditions and possibilities to share and to be involved in decision making are performed in the communication situation (Bülow et al. 2012).

Practices in organizations can be described in many ways, and a basic description of practices is that these are sets of doing and saying, openended actions which are time- and space-bound (Schatzki 2012). Practices begin with a question or situation to handle, then continue with thinking about the situation and trying to understanding what is good, which is guided by moral dispositions to act right. As we think about what we want to achieve, we modify the way we might achieve that, and thoughts and actions are in continual interplay to reach what we want to achieve (Smith 1994). Aspects such as knowledge, meaning, science, power, organized activity, social interaction, and customs are components that are reflected in practices (Schatzki 2012). 
Practices performed in healthcare organizations are always embodied and contextually influenced by the social structures and culture within the organization. Organizational culture are formed and reproduced through interaction emerged through relationships, and organizational goals and statements in form of policies. The organizing of practices within an organization in the care context is linked to how healthcare professionals handle the care situation (interpreting situation), which in turn affects the care of the patient (Ray \& Turkel 2015). Care practices within an organization rely on the outer and inner dimension of the healthcare context they are working in. The care and the meaning of care, the sense (coherence) that the care provided is in constant relation to the structures of the organization (external context). The structure of care is a synthesis between the dimension of acting and caring as humanistic, ethical and spiritual caring, sociocultural, physical and educational (the element of humanism) and the antithesis of care as economic, political, legal and technological (the dimension of bureaucracy). Interactions and symbolic acts of meaning are formed and reproduced from the construction of dominant values held within the organization. These values and dimensions are important in the caring process for the patient (Turkel 2007; Ray \& Turkel 2017).

Routinization within an organization can be linked to the development of quality of care, and the development and delivery of effective routines depends on structuring devices, people and organizational learning. Therefore structures and routines around interpreting practices are of special interest (Greenhalgh et al. 2008). The term routine is used in many different contexts and is a concept that can be described as: a repetitive, recognizable pattern of interdependent actions, involving multiple actors (Feldman \& Pentland 2003). Routines can be referred to as cognitive regularities (rules) or to behavioural patterns (recurrent interaction patterns) (Becker 2004). When talking about routines, two aspects are involved, an ostensive aspect and a performative aspect. The ostensive aspect, which is more the idea of a routine, the history, shapes our perception of what the routine is, knowing that, depending on each actor's personal role and perceptions. On the other hand, the performative aspect of a routine consists of who did what, when and where, knowing how. Routines are a combination of knowing that and knowing how, and the development of changes of routines lies in the tension between these aspects (Feldman \& Pentland 2003). Routines can reflect the dynamics of organizational structures, and routines are described as forward structures for professionals, and a fruitful way for organizational changes (Becker 2004; 2005). 
Organizational routines concerning language interpreting involve five aspects: 1) the individual action includes the person's identity, values, goals and competence; 2) the interpersonal interaction includes levels with social skills, personality, power and influence; 3) the organizational context includes technological, cultural and coordination structures; 4) the institutional context includes the regulative, normative and cultural/cognitive pillars; 5) the environmental context includes the economic/political society, legislative constraints, demographic changes and technological developments. Previous research has shown that frequent use of interpreters is linked to strong and successful routines for interpreting services; these routines can maintain and improve the quality of care (Greenhalgh et al. 2007; 2008).

\section{Aims}

The overall aim of the study was to explore interpreting practices in a healthcare context by comparing two different healthcare areas, elderly and emergency healthcare, with the aim of highlighting the impact of the organizational and institutional context.

\section{The specific aims were:}

To examine issues concerning communication and healthcare through a particular focus on interpretation between healthcare professionals and patients of different ethnic and linguistic backgrounds. The central aim of the project was to explore interpreting practices in multilingual elderly healthcare (Study I).

To describe interpreting practices in multilingual emergency healthcare by studying different healthcare professionals. The study explored the impact of the organizational and institutional context and possible consequences of different approaches to interpretation (Study II). 


\section{METHOD}

\section{Design}

This study is a cross-sectional comparative qualitative investigation with two sub-studies in the areas of elderly care and emergency healthcare (Table 1). These sub-studies are designed as explorative and descriptive to find patterns used by healthcare professionals in a field not previously explored from this perspective, and descriptive to find actions, beliefs and processes occurring when organizing interpreting practices (Patton 2015). To get a variety of experiences and to arrive at a better understanding of interpreting practices, semi-structured individual and focus-group interviews with health care professionals at different levels of the organization were used. This approach was chosen in order to structure and comprehend the reality of organizational issues concerning communication and language interpreting practices in two healthcare areas differing in character, and the effect on the care that is performed (Patton 2015). 


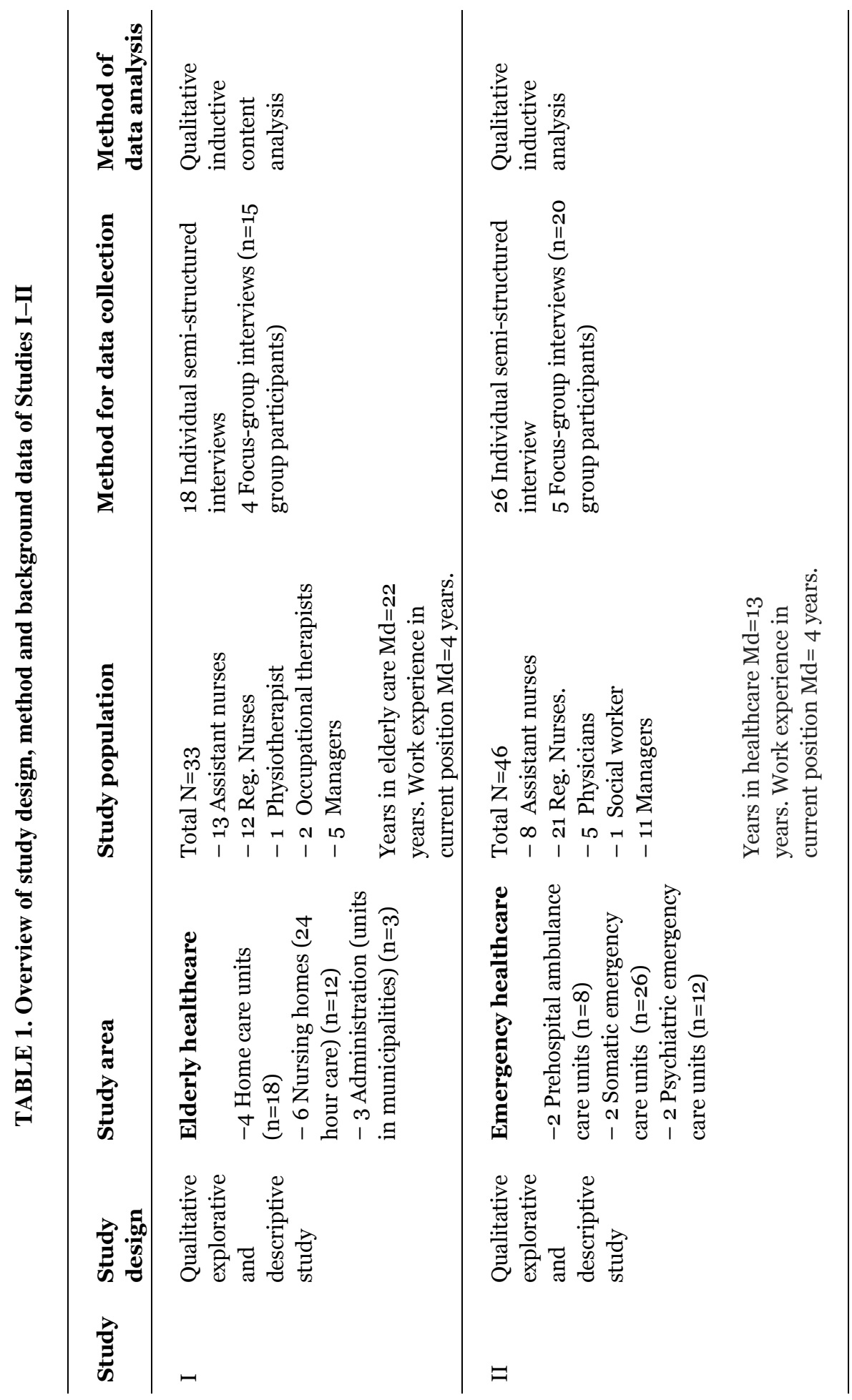




\section{Settings}

The studies took place in elderly care and emergency healthcare institutions in two municipalities and in two county hospitals differing in geographical and demographic contexts. The study included both rural and urban areas with big and medium-sized cities in two different regions in Sweden. In the selected cities there were approximately 89,-500 vs 139 ,-0oo inhabitants, of whom $17 \%$ vs $19 \%$ were foreign-born inhabitants (SCB 2016).

The elderly care institutions were situated in an area with many foreignborn inhabitants, including 11 nursing homes for elderly care with 24hour care, 18 homecare service units for the elderly, and administration units in municipalities. The nursing homes were mainly run by county councils, while a few were run by private enterprise. The residents lived in individual one-room apartments and shared common spaces such as a dining room. The nursing homes provide care for individuals with different physical conditions and short-term care. Home care services in this study consisted of healthcare professionals working by visiting the person's home.

The emergency healthcare institutions were two prehospital ambulance units and two somatic emergency departments (open 24 hours), one with observation wards for a maximum of 48 hours' care. Two psychiatric emergency departments (open 24 hours), one clinic with a psychiatric intensive care unit were also included. The emergency and psychiatric healthcare institutions were run by the county councils. One of the prehospital ambulance units was run by a county council, and one was run by private enterprise.

\section{Participants and procedures}

A purposeful sampling technique was used to ensure variation and information-rich cases to explore the common and special experiences of the individuals in the healthcare area studied, such as age, gender, occupation, and work experiences (Patton 2015). The inclusion criterion for the participants was to have experience of working with interpreters and interpreting practices as health care professionals in the specific health context. 
The study population includes 79 healthcare professionals, 33 respondents in elderly care ( 31 female, 2 male, age $25-63$ years, $M d=45$ ) and 46 respondents in emergency care (32 female, 14 male, age 21-65 years, $\mathrm{Md}=37$ ), consisting of nurse assistants, registered nurses, physicians, occupational therapists, physiotherapists, social workers, assistance officers/care managers, unit managers, operational managers, and recreation leaders (see table 1).

To start the recruiting process, managers at current health care institutions were contacted by the researcher. They were provided with both written and verbal information about the project, to obtain permission to undertake the project at their unit. Once agreement had been granted, health care professionals from different organizational levels with experience of interpreting and interpreting service were invited to participate. A time was arranged for an information meeting where interested participants received written and verbal information about the study from the researcher. Those interested who voluntarily signed up after the meeting were contacted to decide a time and place for the interview. Forty-six respondents were recruited after the information meetings at the workplace and 33 were recruited by asking respondents during the interview period to invite colleagues who had not attended the information meeting held before the study.

\section{Data collection}

Data were collected by semi-structured interview to ensure that the same question is followed with each person interviewed (Patton 2015). The interview guide was based on previous investigations in the area of interpreting (Hadziabdic et al. 2009, 2010, 2011, 2014). The interview guide used was designed with open-ended questions focused on experiences of existing guidelines, routines, why, when and how interpretation should take place.

Data were collected from October 2013 to March 2014 (I) and from December 2014 to April 2015 (II). This thesis is based on 44 healthcare professionals participating in individual interviews and 35 healthcare professionals in nine focus group interviews with three to five participants in each group. The nine focus groups were homogeneous in terms of profession to provide a relaxed group dynamic, interaction and avoid negative power imbalance between different professions. Two groups included managers, three groups included registered nurses, and four groups included assistant nurses. 
The individual interviews allowed the informants to elaborate on experiences and thoughts, to generate data of depth and complexity, while at the same time staying within a certain area (Patton 2015). The focus group interviews had the strength of opening up for discussion where different perspectives were made visible and ventilated. The group interaction also had the purpose of encouraging participants to disclose behaviours and attitudes they might not consciously reveal in a one-onone situation. This means that they might feel more secure, comfortable and anonymous in the group situation when sharing similar opinions or attitudes or simply because they get carried away by the discussions (Krueger \& Casey, 2009).

The first individual and focus-group interview was used as a test of the interview guide (Krueger \& Casey 2009) which led to minor changes. A question was added about the need for guidelines. The interviews were performed by two experienced nurses, both with long experience of leading group discussions, and one of them with long experience of qualitative studies in research on migrants and the use of interpreters. All interviews were held in booked meeting rooms chosen by the participants at their workplace (I, II).

Some of the focus-group interviews were guided with one interviewer and one as a moderator as assistant who took detailed observational notes (I). The individual interviews advanced in an easy and free-flowing way, without interruption, and lasted around 30-60 minutes each (I, II). The focus-group interview was unproblematic with relaxed interaction and intensive and friendly discussions that lasted around 60-90 minutes (I, II). Directly after every interview (I, II), filed notes were done about the atmosphere during the interview, what and how the participant had discussed (Krueger \& Casey 2009; Patton 2015), and in the focus groups to capture the details of the group interaction (Krueger \& Casey 2009). All 44 individual interviews and nine focus-group interviews were recorded digitally and transcribed verbatim by the author and a professional secretary. The field notes from interviews about atmosphere and interaction during the focus- group interviews were read through and used as support for memory in combination with recorded interview and the transcript text (I, II). 


\section{Data analysis}

Qualitative content analysis is described as a method to explore social and human processes, to improve human life as well as improve political and social conditions of life (Krippendorff 2004; Patton 2015). In order to identify main regularities and discover relationships among experiences, the analyses were descriptive and explorative using inductive qualitative content analysis to examine the individual and focus-group interviews. Inductive qualitative analysis starts with specific observation of the content and continues to construct overall patterns, and analysis involves a process of categorization, designed to condense raw data into categories on valid conclusions about individuals' experiences (Krippendorff 2004; Patton 2015).

The analysis in both studies (I, II) started by reading the transcripts from individual and focus-group interviews thoroughly several times, first to check the accuracy and coherency to ensure high quality, then to achieve a sense of the totality. During the analysis of the text the aim of the thesis was in focus (Krippendorff 2004; Patton 2015).

The analysis was guided by Krippendorff's (2004) description of content analysis (I). Krippendorff defines content analysis as "A research technique for making replicable and valid inferences from text (or other meaningful matter) to the context of their use" (Krippendorff 2004, p. 24). After reading the text the first step was to extract and reduce text with core content into smaller textual units addressing different aspects with as much variation as possible. The selected textual units were close to participant's descriptions and in relation to achieve the aim. Then codes with similar descriptions were identified in the textual units and grouped together into groups of coding units. The next step was to search for regularities, contradictions and similarities, and to identify patterns with similar meanings to reduce the coding units and develop preliminary sub-categories. During the whole analysis process, sub-categories and categories were discussed and revised several times by the authors. The five final categories that emerged from the data were developed and modified and refined together with co-investigators until an acceptable system was recognized (Krippendorff 2004).

The analysis was guided by Patton's (2015) description of qualitative inductive analysis (II). Patton defines content analysis as "a general term for identifying, organizing and categorizing the content of narrative text" and inductive analysis as "searching the qualitative data for patterns and themes without entering the analysis with preconceived 
analytical categories" (Patton 2015, p. 551). The analysis involved a process to identify meaning units, make coding units and develop subcategories and finally develop categories. The basic intention of the method is to find patterns and themes in the text, to analyse the core content in the text to describe the patterns found (Patton 2015). The analysis process in emergency healthcare (II) started with reading the text several times, identifying and selecting meaning units relevant to answer the aim of the study. Coding then started by identifying words or text extracts capturing central concepts and named as close to the text as possible. Codes were then sorted in a systematic way by dealing with convergence to find out which codes fit together. This were done by looking for recurring regularities that revealed patterns, and the codes with the same patterns were sorted into groups and counted in order to view the variation of experience in the area.

After grouping codes the next steps was to continue with converges and find regularities within the grouped codes and then sort the groups of codes with similarities into sub-categories. Prioritizing was done according to criteria of usefulness, salience, credibility and uniqueness. The sub-categories were tested for completeness together with the coinvestigators. After analysing for convergence the next step was to examining divergences to fill in the patterns by the process of extension (building on the patterns found), bridging (making connection between patterns) and surfacing (proposing new sets that ought to fit). This process was repeated during a period to reduce several sub-categories into a few categories representing the same pattern and labelled by name close to the primary patterns in the data. This action was helpful for seeing when the sources of information had been exhausted; to see that no new sources lead to more work "moving sets around", and when clear regularities emerged. During this process the co-investigators examined the divergences together (Patton 2015).

The categories in both studies were illustrated with illuminating verbatim quotations representing different professionals at different levels in both organizations (I, II) (Krippendorff 2004, Patton 2015).

\section{Rigor}

To enhance the stringency of the quality aspects of the research product, trustworthiness criteria were applied in the process by the four dimensions of credibility, dependability, conformability and transferability (Patton 2015). 
Credibility concerns the truth in the research findings, and confirmability refers to the degree of objectivity of the researcher and the degree to which the results are supported by the data. Dependability is concerned with the possibility to repeat the study, and transferability concerns the applicability of findings to other contexts (Patton 2015).

The credibility was confirmed by involving different data sources to produce an understanding of the phenomenon (Patton 2015). Data triangulation was used, contributing a variety of experiences of the topic through the number of participants, 79, differing in age and gender, from different professions at different levels in different healthcare areas that can be expected to provide enough data to cover the complexity of the phenomena. Method triangulation was used, with both individual and focus-group interviews, and researcher triangulation was employed to review the findings through the analysis process to strengthen the credibility. A peer-debriefing process was performed in the coding procedure, to reducing the bias of a single researcher. Later on in the process the content of the analysis was reviewed and assessed for the relevance of categories and sub-categories together by a third coinvestigator to ensure that the chosen categories covered the findings in the data.

To ensure confirmability according to Patton (2015) the ambition was to describe the sampling method, the approach to involving respondents, the transcription and analysis process as clearly and distinctly as possible. During the whole process the aim of the study was kept in focus, developing codes, sub-categories and categories named as close to the text as possible. To achieve objectivity, the data were analysed by the two authors, first independently and then together, comparing the content of the codes. The reason for analysing independently and together was to select the most suitable meaning units, not too broad or not too specific to contain various meanings and to keep data closely connected to the source before continuing the analysis process. Quotations have been used, representing the different professionals, healthcare areas and their working level in the organization, to illustrate the range of experiences of the phenomenon.

To enhance dependability in the study the ambition was to describe al steps carried out in data collection and analysis process (Patton 2015). Dependability was confirmed by the description of the investigators' experiences in research and nursing. To ensure traceability, each interview was transcribed verbatim and the material are saved, sorted and 
named with codes for each individual, quotation, and unit involved, which can be tracked by identification lists. Written field notes were taken during the interview period and saved, about the atmosphere in interview situations. Reflection notes were written during the whole process and also notes about the ongoing activities as a researcher. The method of analysis has been followed strictly and the research process has been described as clearly as possible to minimize bias, and also so that other researchers can follow the plan used.

To facilitate transferability according to Patton (2015) the ambition was to give a distinct description of the different contexts and settings used, the characteristics and number of participants, the data collection used, and the process of analysis sought to be as informative as possible to provide data that make transferability judgements possible for other researchers. To present the findings is as much detail as possible together with representative quotations can also enhance transferability.

\section{Ethical considerations}

According to Swedish regulations on ethical guidelines, approval by an official research ethics committee was not required as the investigation posed no physical or mental risk to the informants and did not treat informants' personal data (SFS 2003:460). Ethical considerations of research involving humans followed Swedish law (SFS 2003:460) and ethical considerations according to the Declaration of Helsinki (Helsinki Declaration 2013) were followed. The guidelines ensure written informed consent, right to self-determination, confidentiality and beneficence. Written informed consent was used and involved providing information in writing and verbally, before the interviews started, about the purpose and design of the research. Participants were informed about the voluntary nature of the study and that they could withdraw from the study at any time without explanation. The participants have the right to selfdetermined participation in the study. To ensure confidentiality, that private data would not be disclosed, the participants' data were secured by having the digital files and transcripts anonymized and coded by number. The analysis and presentation of the data were done in a way that concealed the participants' identity. All data were stored in a locked space to which only the author had access (Helsinki Declaration 2013; SFS 2003:460). 
To guarantee confidentiality in the focus group, each participant was asked to maintain the respect and feeling of self-worth of everyone in the group, and not to share what was said in the group outside the group (Krueger \& Casey 2009). The researcher and interviewer were aware of the possible consequence of the risk of harming the participants or the larger group they represented. No aspects of being harmed have been noticed by the interviewer during the study (Helsinki Declaration 2013; SFS 2003:460). There was no dependent relationship between the informants and the researcher. 


\section{FINDINGS}

The main findings show that the processes and structures around interpreting practices were complex and mainly linked to individual and interpersonal levels and, to a limited extent, to the institutional level. On the institutional level the Public Procurement Act was the only formal policy to follow. On individual and interpersonal level interpreting practices were structured by self-established informal workplace routines developed by the professional groups. The norms and routines used was determined by access to interpreters, time aspects, characteristics of the care given, health conditions and the person's problem, expectations and requests from the person and also from healthcare professionals. There were wishes for improvement, with better flexibility in access to professional interpreters, training for users and interpreters, and also better technical solutions and equipment.

Categories in elderly healthcare (I) and in emergency healthcare (II) emerged from the analysis of the interviews about how healthcare professionals experience interpreting practices and the impact of the organizational and institutional context. Table 2 presents the categories:

Table 2. Categories in elderly and emergency healthcare

\begin{tabular}{|l|l|}
\hline Elderly healthcare & Emergency healthcare \\
\hline $\begin{array}{l}\text { Organization of interpreter practice in } \\
\text { multilingual elderly healthcare in } \\
\text { accordance with the Public Procurement Act }\end{array}$ & $\begin{array}{l}\text { Healthcare professionals in emergency care } \\
\text { regulate use and booking of interpreters in } \\
\text { care situations with communication barriers, } \\
\text { mainly based on informal and in some cases } \\
\text { formal guidelines and different national laws } \\
\text { work }\end{array}$ \\
$\begin{array}{l}\text { The professional interpreter's role in } \\
\text { communication in everyday multilingual } \\
\text { elderly healthcare. }\end{array}$ & $\begin{array}{l}\text { The patient's health status and access to } \\
\text { interpreter service in the organization } \\
\text { determine the use }\end{array}$ \\
$\begin{array}{l}\text { Healthcare and communication practices for } \\
\text { non-Swedish speaking elderly }\end{array}$ & $\begin{array}{l}\text { The use of an interpreter at the workplace } \\
\text { depends on the interpreter's linguistic skills, } \\
\text { personal qualities, professional approach, } \\
\text { and organizational aspects }\end{array}$ \\
$\begin{array}{l}\text { Wishes for future development of } \\
\text { interpreter practice in multilingual elderly } \\
\text { healthcare }\end{array}$ & $\begin{array}{l}\text { Wishes for future development of use of } \\
\text { interpreters in emergency care }\end{array}$ \\
\hline
\end{tabular}




\section{Organization of interpreting services regulated by healthcare professionals, based on informal guidelines with varying knowledge of national laws}

The majority of healthcare professionals are not aware of any specific law or policy regulating the use of an interpreter and there is a lack of guidelines on how and when to use an interpreter (I, II). Healthcare professionals are mainly aware of the Public Procurement Act governing routines for how to book a professional interpreter (I, II). The established policies used included how to access an interpreter agency, which the workplace had ensured in accordance with the Public Procurement Act (I, II). There were considerable similarities between elderly healthcare and emergency healthcare as to how the organizations had developed formal policies for how and where to order professional interpreters (I, II). Both organizations had established formal policies for providing professional interpreters according to the Public Procurement Act. The institutions differ in that in elderly healthcare the decision to order a professional interpreter is more based on needs in the organization to inform the elderly about medical issues and decisions concerning assistance (I). In emergency healthcare, the decision to order a professional interpreter has a wider variation and is more based on the person's needs and current health status (II). In elderly healthcare booking a professional interpreter was mostly managed by nurses or care managers (I), whilst in emergency healthcare it was managed by nurses or nurse assistants (II).

Healthcare professionals found interpreting practices to be wellfunctioning because the established policy for which agency to select was good. However, they also found problems with interpreting agencies concerning inflexibility since face-to-face interpreters were not easily accessible at short notice, requiring long planning in advance (I, II). In elderly healthcare informants described interpreting service as being restricted to office hours, and this required planning in advance, which affected the use of professional interpreters in day-to-day work (I). In somatic emergency healthcare phone interpreting by professional interpreters was used outside office hours on unpredictable occasions for short-term assignments (II). 
At organizational level there were similarities in the way that managers described that they rarely come in contact with professional interpreters (I, II). Medically responsible managers, and care managers in elderly healthcare described their contact and organization of the use of interpreter in terms of efficiency, accessibility, professionalism and equity for the elderly (I). Care managers in emergency healthcare mostly came into contact with issues concerning interpreters and interpreting when healthcare professionals experienced difficulties or when they handled the cost or issues of patient safety (II). When it comes to terms of cost for ordering a professional interpreter, healthcare professionals in emergency healthcare felt no restrictions from their managers (II). This perspective was not described or expressed in elderly healthcare.

The individual engagement of staff working closely with the care recipient was described as the driving force for decisions about the need for a professional or informal interpreter. Healthcare professionals stated that the indication to arrange for an interpreter depended on the personal feeling emerging in the actual healthcare encounter. The feeling was described as a need for an interpreter to be able to understand each other. The need for language support was also based on the person's entitlement to an interpreter's in order to understand information given (I, II). Without any existing guidelines regarding when, how and what type of interpreter to use, self-established informal routines had been developed by healthcare professionals with knowledge mainly based on older colleagues experiences (I, II). The majority of professionals were pleased with these self-established informal routines developed at an individual and interpersonal level in the organization (I, II).

\section{Healthcare professionals' perceptions and experiences of interpreter use and organizing interpreting practices}

The majority of healthcare professionals who used professional interpreters had a positive understanding of and attitude to interpreters, also concerning the use of professional interpreters at the workplace. The majority of healthcare professionals who used professional interpreters had a positive understanding and attitude when it came to interpreters, also the use of professional interpreters at the workplace. They saw the professional interpreters as a solution to the language problem with a role of "mouthpiece" that transfers spoken language (I, II). 
However, healthcare professionals have experiences of using a variety of interpreters with a span between professional interpreters and the use of body language (I, II).

To promote language-adapted communication both organizations had established informal routines developed by individual professionals to regulate how to choose and use different types of interpreters (I, II). The norm developed in both elderly and emergency healthcare was to use professional interpreters frequently related to well-planned medical encounters with a physician in connection with "need assessment" and "care decisions" (I, II) or "need assessment" by care managers (I). Bilingual staff or family members were often used as a norm for interpreting in everyday care or nursing care situations, in situations of haste and for unpredictable requirements at short notice (I, II). As compared to the above situation healthcare professionals in ambulance care used family members to interpret or body language when language barriers occurred, since professional interpreters were absent in their context because of organizational issues. Such issues could be lack of space in the ambulance and not knowing in advance what language the person spoke (II). Many healthcare professionals said that they preferred, if possible, to use professional interpreters, and if possible in place, face to face (I, II). The limitation that the healthcare professionals expressed about using professional interpreters was the difficulty of obtaining a professional interpreter at a particular time to suit the needs of the context (I, II).

From the experience of using professional interpreters a common concern among healthcare professionals was uncertainty about the professional interpreter's competence (I, II). The skills that facilitated the interpreting situation were the interpreter's professional approach, being neutral and observing the confidentiality agreement. Furthermore: to have linguistic competence, translating word by word and being familiar with healthcare terminology relevant for the context (I, II). In elderly healthcare the professional interpreters were also expected to have the ability to adapt to elderly people's different illnesses such as dementia and elderly people's way of using the language. There were also expectations on the interpreter that included translating written information, for example the weekly food menus (I). In emergency healthcare the healthcare professionals stressed that it facilitated the actual situation if the professional interpreter could translate with a flow, with good conversation technique (II). 
One limitation in organizing language-adapted communication in relation to all the different types of interpreter could be deficiencies in the quality of the interpreter's linguistic competence or if the chosen interpreter not could contribute an approach that promoted interaction and trust (I, II). Working as a healthcare professional with support of a professional interpreter, or bilingual staff, or family member as interpreter included feelings of insecurity about whether or not the information was correctly translated (I, II).

Healthcare professionals described how relational aspects impact the organizing of the interpreting situation (I, II). In elderly healthcare the elderly people's own concern about not being able to obtain an interpreter from the same country of origin and dialect can affect the relationship and the interpreting situation (I). In emergency healthcare the professional interpreter's ability to establish a trustful relationship was important, as was the ability of the interpreter to exercise self-control in the emergency care situation (II). The patient's own feelings could sometimes be seen as a barrier to the relationship as well, e.g. in care when the patient did not feel well because of emotions like fear or anger which decreased their ability to receive information (II).

Structuring aspects also impact the organization of interpreting. A positive outcome would be if healthcare professionals could have an undisturbed environment so they could maintain confidentiality, or if the interpreter was available to stay for a period of time to match the physician's possibility to use the interpreter in the ongoing medical scheduling, and also if the interpreter could stay longer if needed (II). Structuring aspects concerning phone interpreting also occurred and were perceived as positively or negatively impacting the interpreting situation depending on how the technical equipment functioned or not (I, II).

\section{The characteristic of the care given and the person's needs and health situation as determining factor for interpreter use}

The characteristics of the care performed, such as the need of information exchange about the person's health status, e.g. assessment of the person's condition, explanations of symptoms or information about treatment (I, II), 
or in critical conditions, diffuse conditions, and complex care situations (II) or in case of care planning by managers (I) were all determining factors when a professional interpreter was required and used.

Professional interpreters were not used in urgent situations or in the case of severely ill people or people with lowered consciousness; then bodily parameters and observations were used to assess the person's status (II). Body language or bilingual colleagues or family members were used as language-adapted communication in everyday care situations and for unpredictable requirements at short notice in elderly healthcare (I), or in short encounters in emergency healthcare, or when the caring activity had to take place without delay (II). Body language or bilingual colleagues or family members were also used in nursing care to sort out the admittance of the person to the emergency unit (II), or in situations where nurses had to assess a person's health condition (I, II), or perform nursing care e.g. meal situations or assessment of pain (II).

If the person needed security and comfort, a family member who could stay calm and objective was used as interpreter with positive effect (I, II). Using family members as interpreters also made it easier for the healthcare staff to get information concerning the person's healthcare status, and as an integral part of the care relationship (I, II). At the same time it was considered easy to convey information concerning the relatives (II). To use a calm and objective family member as interpreter was considered a great advantage, especially in ambulance care, since one limit in using professional interpreters was the lack of knowledge concerning the language spoken by the patient that needed attention (II). Healthcare professionals stated that using family members as interpreters had also been associated with a poorer quality of interpreting situation because of lack of neutrality, limited knowledge of official terminology and language skills. Sometimes severe emotions influenced the use of family members as interpreters, especially when the family member had to interpret negative and/or sensitive information (I, II).

In psychiatric emergency care family members were seldom used as interpreters because of the risk of breaking the code of confidentiality (II). Healthcare professionals describe how elderly people suffering from dementia and/or aphasia need to have someone that they recognize, such as a family member or a well-known staff member. The decision to refrain from having a professional interpreter could for example be taken in care situations where the person may feel uncomfortable with strangers in the healthcare encounter (I). 
In a situation where the patient expressed personal expectations, showed uncomfortable behaviour or had cognitive symptoms, it was thus sometimes determined not to enlist a professional interpreter (I, II).

The health status of the person also determines the form of interpreter used, ranging from face-to-face interpreting to interpreting by telephone. The use of different forms of interpreting differed between the healthcare contexts, and the healthcare professionals in elderly healthcare found that the use of phone interpreting entailed several difficulties. Communication by phone requires a certain functional ability from the elderly person, who often is unable to follow the body language and might feel discomfort about using technical equipment (I). For patients in psychiatric emergency care with mental health problem, such as speaking low because of depression, or having delusions, led to the use of face-to-face professional interpreters in the treatment room instead of phone interpreting. The reason was that phone interpreting could be perceived as suspicious by the patient (II). Using phone interpreting in somatic emergency care had also been experienced as an obstacle in examination situations since the interpreter was unable to observe body language shown by the physician (II). When using phone interpreting the technical equipment also determined the quality of the interpreting service used, since it sometimes worked badly, making it difficult to hear, and also was related to the lack of good equipment at the workplace (I, II).

Using bilingual staff was seen positive by professionals since they benefit the care situation because of their familiarity with the duties, roles and routines that exist at the workplace (I, II). At the same time healthcare professionals in elderly healthcare said that using bilingual staff could also be perceived as negative because the elderly person might feel dependent on the staff, with the consequence that they might disclose certain things, especially concerning complaints about the care received (I). Some bilingual staff noticed when they acted as interpreters that the elderly persons had other expectations on them to be available in duties that were not included in their work as assistant nurses (I). Bilingual staff used as interpreters felt exploited by employers since this not was a part of their work assignment (I). Bilingual staff used as interpreters could also be blamed by other professions for interrupting with ideas in the planning of the care situation (I, II). 


\section{Professionals' proposals for improving the organization of interpreting practices}

In both elderly and emergency healthcare professional interpreters were mainly used in predetermined situations, but healthcare professionals also expressed a wish to get easier and faster 24-hour access to interpreters in daily situations, and preferably with fast phone contact for quick translation in unforeseen situations. The reason behind the wish was that the occurrence of language barriers cannot be foreseen (I, II). Many healthcare professionals ask for better access to interpreting in the most common languages as well as in all languages (I, II). Professionals in both elderly and emergency healthcare discussed how better technology and technical solutions could improve interpreter use. There was a need to develop the technical interpreting tools that can be used by healthcare staff in the daily care encounters (I, II).

Professionals called for more education and training in how to act with interpreters to ensure adequate communication. Training encompasses the actions and characteristics of the interpreting situation with their impact on communication (I, II). In elderly healthcare the procedure for using an interpreter could be simplified and could be improved by making the policy on the use of interpreters accessible and easy to understand for all employees at the workplace. Healthcare professionals suggested that this could be done on the organizational level, making the policy accessible and readable on the workplace's internal website (I). They also wanted basic practical training about how to get access to interpreter service, and having a person with responsibility to continuously educate healthcare staff about the guidelines, rules and procedures concerning interpreter use (I). In order for an elderly migrant person to communicate in daily life and not only on special occasions, some healthcare professionals suggested planning regarding the placement of nonSwedish elderly persons in the proper department, with bilingual healthcare staff available (I). Another suggestion was to employ more healthcare staff with different cultural backgrounds to increase the possibility of easy access to interpreters at short notice (I). Some informants felt that the care and possibilities to participate would be improved if interpreters could translate written information such as the menu, information about chronic illness or daily activates (I). 
Emergency healthcare would improve if the administrative staff helped to book an interpreter. The healthcare professionals also wanted to use interpreters more frequently in nursing care situations (II). In ambulance care all types of professional interpretation would be a help to make it better for the patient and healthcare professionals, and it would be a help if the SOS alarm staff booked an interpreter in advance, so that the interpreter was available already at first contact (II). 


\section{DISCUSSION}

This study is the first to explore and describe the organizational perspective of interpreting practices in elderly and emergency healthcare. The main findings show that the processes and structures around interpreting practices were complex and mainly linked to individual and interpersonal levels and, to a limited extent, to the institutional level. On the institutional level the Public Procurement Act was the only formal policy to follow. On individual and interpersonal level interpreting practices were structured by self-established informal workplace routines developed by the professional groups. The norms and routines used was determined by access to interpreters, time aspects, characteristics of the care given, health conditions and the person's problem, expectations and requests from the person and also from healthcare professionals. There were wishes for improvement, with better flexibility in access to professional interpreters, training for users and interpreters, and also better technical solutions and equipment.

\section{Discussion of results}

This study shows that the only formal policy used as a guideline for healthcare professionals regarding interpreting practices is about where and how to order professional interpreters according to Public Procurement Act (SFS 2007:1091). Many professionals are aware of the Public Procurement Act (2016:1145), but expressed limited knowledge (I, II) about the Public Management Act (SFS 1986:223) the legal framework for interpreting practices in healthcare as well as the Social Services Act (SFS 2001:453), the Health and Medical Services Act (SFS 2017:30) and the Patient Act (SFS 2014:821), other laws regulating a person's right to participate in decisions and obtain information concerning health. To work without guidelines can be challenging for healthcare professionals in their work maintaining an equitable and consistent quality concerning interpreting services. They seemed to have difficulties to apply Swedish laws and might need support at the workplace to keep and obtain knowledge concerning laws that support the work with interpreting practices.

These results suggest that common guidelines based on legal regulations should be developed in order to improve the conditions for an individual's 
right to have an interpreter in contact with healthcare institutions. Common guidelines can ensure that the use of interpreters can be more consistent and based on best practice according to legal regulations, and similar decisions can be taken by professionals that ensure equal use of interpreters in line with the goals of the organization. To obtain the same knowledge in all members of staff at all levels in the institutions, nurse assistants (I) and physicians (II) probably also need support in how to order an interpreter according to the Public Procurement Act.

A new finding, not previously described, is that interpreting practices are predominantly structured by internal processes, based on a variety of routines developed by the professional groups with engagement as a driving force, and on positive attitudes to interpreters and interpreting processes (I, II). The existing routines used, established by colleagues with longer experience about when or what form or type of interpreter to use in different care situations (I, II), seem to give the stability to the interpreting services offered in this organization. The absence of coordination at organizational level concerning interpreting services within the whole organization (I, II) can be seen as a limitation for the strong routines needed to build up interpreting service of high quality (Greenhalgh et al. 2007).

The informal routines used by healthcare professionals in the study were expressed as routines that had been more directly observable and consisted of who did what, when and where, concerning knowing how (I. II). By bringing more awareness about existing routines, looking not only at how they do things, but also what is behind the use of the routine, concerning knowing that, it would be possible to develop more solid routines (Feldman \& Pentland 2003). To know why different form and type of interpreters are used in different care situations, can promote forward structures and enable coordination and maintain some stability in behaviour for professionals (Becker 2004; 2005). Cooperation within the whole organization is required to find how and why different interpreters are used to construct the strong routines needed to achieve the best outcome of communication (Greenhalgh et al. 2007).

When routines for care are to be structured by cooperation within organizations Ray and Turkel (2015) emphasize that the deep values that underline caring and choice to do good for patients need to be highlighted since they are factors contributing transforming caring organization to be more relational. They also stated that the care and meaning given to the care is in constant relation to the organizational structures and cultural 
patterns, and therefore the meaning of care needs to be considered in relation to communication situation and interpreting practices. In this study the engagement and positive attitude from the staff concerning interpreting practices (I, II) might reflect that elements of humanism, ethical and spiritual care are values used by professional groups within the organizing of interpreting service (Turkel 2007; Ray \& Turkel 2015). The theory of bureaucratic caring grounded in dimensions of humanism and bureaucracy can provide direction and guidance to understand the way caring is performed and expressed throughout health organizations. The structure and meaning of care is created between these elements and highly depending on its structures. To understand the impact of the dimensions regulating care and to strive for care balanced between these two dimensions (Turkel 2007; Ray \& Turkel 2015) might contribute to the building of strong routines for high-quality communication. To do good for patients can also concern the balance of power and control in the conversation, since previous studies show that no matter what type of interpreter is used, there can be an imbalance concerning which of the actors involved wants to have power and control over the conversation (Lenaza et al. 2010; Brisset et al. 2013).

One aspect that can affect the health of migrants is the informal routine used in both elderly and emergency healthcare and expressed more as a norm, stating that professional interpreters were ordered in medical encounters performed by physicians (I, II), or care managers in authority decisions concerning individual care planning (I), this despite the differences in healthcare performed in the different contexts. The norm used, constructed by the professional groups, was not explained further by the staff. The actions performed and the norm used might reflect patterns in the variation of dominant values, social structures and the culture held within the healthcare areas, which in turn impact the care given to the person (Turkel 2007; Ray \& Turkel 2015). If there is a deficiency of nursing care for people in need of interpreter this can affect the care recipient in a negative way since communication in caring situations is often an important care activity in itself to create meaningful meetings. Care should have the objective of helping patients to process feelings and reduce suffering, and also to promote ability to help the patient to learn self-management strategies for care (Leininger \& McFarland 2006). In this study the person in need of language-adapted communication seldom had access to all professional groups' expertise in contact with healthcare (I, II), as also shown in a previous study where nurses seldom used interpreters in caring situations (Schenker et al. 2011). The imbalance between the professionals' use of interpreters can be a limitation in participation for the care recipient, and contributes to 
unequal healthcare. The routines developed at the individual and interpersonal level in the organization can reflect how the care performed depends on the social and cultural context within the organization (Leininger \& McFarland 2006; Ray \& Turkel 2015).

In this study many healthcare professionals preferred the use of professional interpreters and if possible in place, face to face (I, II), which contributes to good quality in communication according to previous research (Flores 2005; Karliner et al. 2007; Ramirez et al. 2008). Finding the best quality of communication using an interpreter is important to reduce miscommunication since language barriers are central risk factors in relation to healthcare for migrants (Hampers et al. 1999; Bischoff 2003; Ramirez et al. 2008; Bauer \& Alegria 2010; Seffo et al. 2014; Ventriglio et al. 2014; Njeru et al. 2015). Good quality of communication is very central to the health of migrated people (Leininger \& McFarland 2006), since migration and integration can lead to positive or negative consequences for the health of the individual (Albin et al. 2005; Wallace \& Kulu 2014; Syse et al. 2016). In order for elderly migrants in elderly healthcare to have equal living conditions, and for patients in healthcare, the quality of communication using interpreters is essential to manage to maintain regulations regarding respect, self-determination, human dignity, the feeling of well-being and participation in care and at the same time ensure equal care for migrants (SFS 2017:30; SFS 2014:821; SFS 2001: 453).

However, the lack of professional interpreters was a determining factor for interpreting practices. It was also difficult to get an interpreter face to face since it required booking a long time in advance (I, II). Lack of qualified interpreters is in line with previous international research in healthcare (Ginde et al. 2010; Kale \& Syed 2010) and also in line with the lack of trained and authorized interpreters in Sweden (MYH 2010; SNBHW 2016c). Healthcare professionals in both institutions emphasized the gap between their needs and wishes and the precondition for performing interpreting practices (I, II) and the result might be a compromise. This situation shows that the perspective from the environmental context including the economic/political aspects must be taken into consideration to fully develop interpreting practices in healthcare institutions (Greenhalgh et al. 2007).

Healthcare professionals in elderly and emergency healthcare enlisted a variety of interpreter types, or used body language to communicate and professionals seemed to act as gatekeepers for migrant's access to 
interpreters. The use of different interpreters was dependent on the person's needs and health situation, the characteristics of the care given, expectations and requests from the care recipient and from healthcare professionals, and also the quality of the interpreter's linguistic and relational ability (I, II). This confirms previous research that different types of interpreters are used in healthcare, sometimes professional interpreters are preferred (Bernstein 2002; Karliner et al. 2007; Ramirez et al. 2008; Bagchi et al. 2011) and sometimes family members or bilingual staff are used and preferred (Gerrish \& Clayton 2004; Edwards et al. 2005; Fatahi et al. 2008; Rosenberg et al.2008; Hadziabdic et al.2014). The result of this study shows that interpreting practices are complex and the care performed in different healthcare areas impacts decisions about what type of interpreter to use, meaning that organizing interpreter services can benefit from being adapted to the specific context.

The characteristics of the care performed in different healthcare areas also seem to impact the decision about what type of interpreter to use (I, II) In elderly healthcare bilingual staff (sometime family member) were used as interpreters more as a norm to solve translation in everyday activities, and the use of bilingual staff has both positive and negative outcomes for the elderly and the employee (I). It is positive in that it gives trust, a familiar face for the elderly person, and staff's knowledge about the person's needs (I), also confirmed in previous research showing positive aspects of using bilingual staff as interpreters in everyday activities (Ramirez et al. 2008; Hadziabdic et al. 2009; Hadziabdic et al. 2014). The use of bilingual staff can contribute to the cultural understanding among professionals and ensure that individual cultural beliefs and values are considered when caring for people (Leininger \& McFarland 2006). Using language-concordant care by bilingual staff can also be positive as a proactive way to organize language and cultural support in elderly healthcare, as recommended in the national guidelines for the care of people with dementia (SNBHW 2016 b) and as a solution for migrants who need language-adapted care (SNBHW 2016 a).

The use of bilingual healthcare professionals not trained for the task, with a double function as both caregiver and interpreter, was also described in negative terms for the elderly person, being in a dependent situation, not being comfortable about complaining (I). This finding is also described in previous research, stating that communication barriers can be raised because of non-neutrality and problems of confidentiality through the use of bilingual staff or family members as interpreters (Hadziabdic et al. 2013). This double function was described in negative terms by the healthcare professionals who felt exploited by employers and also by the 
elderly persons who had other expectations of duties which were not included in the professionals' work tasks (I). The use of bilingual staff as interpreters as the best option in elderly healthcare is currently a actual issue, since recommendations in national reports in Sweden suggest that bilingual staff can be used as a language aid in elderly healthcare (SNBHW 2016 a, 2016 b). The cultural understanding in the healthcare institutions as well as the cultural background of the individual professional has become more important in organizational issues (Kirmayer 2011) since Swedish workplaces have become more multilingual due to the ongoing global migration (Gunnarsson 2014). The use of bilingual professionals as interpreters in everyday situations in elderly healthcare (I) can reflect the daily need of translation and the elderly people's need of interpreting face to face with someone they know that shares cultural beliefs and values and can act as a link between language and culture (Leininger \& McFarland 2006; Linell 2011). To use bilingual staff as interpreter can be both positive and negative which need to be considered when organizing for interpreting services in elderly healthcare.

Another aspect to take into account concerning interpreting practices in health institutions is from research analysing language interpretation in the context of maternity healthcare that emphasizes how racialized discourses can take different shapes in different institutional contexts (Bredström \& Gruber 2013). In relation to interpreting practices, it is important to be aware of how professionals discuss and reason about language interpretation in the workplace and how care recipients can participate in communication situations to exert influence and to reach the goal of equal healthcare (Lill 2007). Society's responsibility to assist migrants to gain legal and health literacy to manage health care visits is also of great importance for achieving social justice (Vissandjée et al. 2017).

The education and training requested by professionals mostly concerned practical issues of how to order and use interpreter, and the development and use of more technical solutions (I, II). These findings do not tell us anything about other competences needed in the organizations, but to improve interpreting practices knowledge concerning regulatory laws, the function of language for a person, knowledge about ethnicity and culture in relation to healthcare to perform conversation based on cultural understanding can also be of interest.

The professionals' proposal for a change of the interpreter's role and task to possess qualities such as the ability to create confidence and have 
knowledge of the context (I, II) or to translate documents (I), is a question for societal/political level. The interpreter's role has also been discussed in previous research, showing a need to extend the role also as mediator and a bridge between cultures (Rosenberg et al. 2008; Messias et al. 2009; Hsieh \& Kramer 2012).

The results in this study also confirm previous findings showing that healthcare institutions need to realize that interpreting issues is a complex linguistic, communicative (Janson \& Wadensjö 2014) and social practice with a complexity that needs to be handled through the whole organization and also on a national level (Hadziabdic et al. 2011; Janson \& Wadensjö 2014; Hsieh 2015).

\section{Methodological discussion}

The aim of the study was to explore the reality of interpreting practices in order to get a deeper understanding of the phenomena (Krippendorff 2004; Patton 2015). The studies in this thesis have both methodological strengths and limitations that need to be taken into account when reading the findings and drawing conclusions.

The design used with comparative qualitative investigations (Patton 2015) with two sub-studies has contributed positively to describe and discover what the salient actions, beliefs, attitudes and social structures and processes are concerning language interpreting practices within the different healthcare areas. By comparing interpreting practices in two different healthcare areas including different groups of healthcare professionals in different geographical locations, similarities and differences associated with the context could become clearer. It contributes a broader picture of healthcare staff experiences, beliefs, attitudes, social structure and processes concerning language interpreting practices in elderly and emergency healthcare.

There are different rules for sample size in qualitative studies depending on the aim and the purpose of the study and the amount of useful data obtained (Patton 2015). The number of participants, from different healthcare professionals including managers, contributed a rich amount of data and variation of experiences of the phenomenon, which is a strength of the study.

It was positive to include elderly healthcare institutions in areas with many inhabitants born abroad, since this comprised healthcare 
professional with experiences of interpreting practices. The sampling method used, to reach informants not initially included by asking for recommendations from interviewed informants, might have led to participants from a limited network of professionals, and the quality of the recommendations might have been affected depending on whether the recommending informants trusted the researcher or not (Patton 2015).

To strengthen the findings, a combination of different methods for data collection was used (Patton 2015). Using individual interviews facilitates for participants who are uncomfortable about sharing experiences in a group. The focus-group interviews, on the other hand, stimulated participants to react to others' experiences (Krueger \& Casey 2009). With three to five persons in the groups, interaction in the groups was very good and led to wide variation and deeper expression of experiences. A weakness in study II could be that focus-group interviews were performed with one interviewer and no moderator taking observational notes during the interviews regarding the interaction in the group. Since both interviewer have had lots of experience of leading and documenting interactions in groups, one as researcher and one in clinical supervision of nurses, this has probably not affected the data collection.

Conducting the individual interviews separately by two authors as interviewers can be a limitation for the quality of the interviews (Patton 2015). To prevent deterioration in quality, semi-structured interviews based on an interview guide were used to ensure that all interviews followed a standardized structure. Also continuous cross-checking took place between the two authors who conducted the interviews, which assisted in keeping similar structures during interview situations (Patton 2015). The use of open-ended questions was a strength of the study, because it gave the participants opportunity to talk freely about their experience, giving data rich in detail.

In the studies the transcribed texts from the different settings and different professions within each healthcare area were analysed together and generated two large bodies of material. To explore patterns of similarities and differences in the different healthcare areas, these were kept together and followed through the analysis process in both studies. To let the analysis process be guided using different descriptions of content analysis processes, those by Krippendorff (2004) (I) and by Patton (2015) (II), was neither a strength nor a limitation to the study since the two processes are very similar. 
Since there is limited previous research on the organization of interpreting service in healthcare, the use of different theories when reflecting on the findings can be seen a strength of the study (Patton 2015).

The results of this study cannot be generalized and transformed to speak for all healthcare professionals' experiences. However, professionals in other healthcare areas might have similar experiences, and several professional groups in different healthcare areas in this study had homogeneous experiences. Describing the characteristics of the informants, the context and settings used, and the data analysis process, might contribute to the applicability of findings to other healthcare areas (Patton 2015), although further studies of other healthcare areas are needed. 


\section{CONCLUSIONS}

In conclusion, the use of interpreters was rooted in the organizational environment of interpreting practices, including the availability of laws, policy and guidelines, and closely related to individuals' language skills, cultural values and social factors. The use of professional interpreters was based on the nature of care in context and access to interpreters and determined by health professionals' estimation of the person's current health status in order to deliver fast and individualized care based on humanistic values.

The study provides knowledge about how organization of interpreting services can take place in different care contexts. The findings emphasizes that language interpreting practices in elderly and emergency healthcare can be improved by identifying and evaluate informal and daily routines used. The organizational level needs to take a coordinating role to identify which purpose and goal to achieve with interpreting service when developing routines. Guidelines concerning use of interpreters and knowledge about existing laws and cultural awareness need to be developed. The professionals' wishes for better technical solutions, better access to and training of interpreters and also training in how to use interpreters need to be considered. However, there is a need of further research regarding how persons in contact with elderly, emergency and other healthcare areas perceive and experience the use of different interpreters and interpreting services received. 


\section{SVENSK SAMMANFATTNING}

Avhandlingen berör vårdpersonals erfarenheter av tolkanvändning och organisering av tolkservice inom äldreomsorg och akutsjukvård. Organisering av tolkservice är av stor betydelse inom Svensk hälso-och sjukvård då antalet personer som inte talar svenska har ökat inom vården till följd av omfattande global migration. För att tillgodose vårdtagares behov av kommunikation med god kvalitet i vårdsituationer, och se till en patientsäker och jämlik vård för alla invånare, behövs en optimal tolkservice

Tidigare forskning har visat att missförstånd mellan vårdtagare och personal är vanligt på grund av språkbarriärer i samband med vårdsituationer. Språkbarriären beskrivs som hinder för personer att söka vård, och som en riskfaktor för människors hälsa på grund av ökad risk för feldiagnoser och begränsad tillgång till diagnostisk provtagning och behandling. Språkbarriär leder också till att patienten blir kvar längre på sjukhus, och att patientsäkerheten minskar.

Forskning om tolkningspraxis har genomförts med vårdpersonal, tolkar och patienter kring deras erfarenheter av kommunikation genom tolk, användningen av tolkar, samt problem i samband med tolkning, liksom faktorer som påverkar valet av olika typer av tolk. Studier har visat att tolkens roll, förhållningsätt och språkliga kompetens inverkar på vård mötet, liksom organisatoriska problem vid bokning av tolk, likväl tekniska problem med utrustning. Att använda professionell tolk bidrar till ökad kommunikationskvalité, något vårdpersonal och patienter uttrycker att de oftast föredrar att använda. Familjemedlem eller personal används också som tolkar vilket kan medföra både positiva och negativa följder för tolksituationen.

Dock saknas kunskap kring hur tolkningstjänster organiseras i olika hälsovårdssammanhang. Därför är hälso- och sjukvårdspersonal erfarenhet av tolkningspraxis och rutiner viktiga att studera för att förbättra kommunikationssituationer och utveckla organiserad tolkningstjänst av hög kvalitet och som leder till jämlik vård. 
Avhandlingens övergripande syfte var att undersöka vårdpersonalens erfarenheter av tolkanvändning inom två olika vårdområden genom att jämföra äldreomsorg och akutsjukvård. Avhandlingen avser att belysa inverkan av det organisatoriska och institutionella sammanhanget. Avhandlingen bestod av två delstudier med syfte att: Undersöka vårdpersonalens erfarenheter av tolkanvändning inom äldreomsorg (studie I), samt vårdpersonens erfarenheter av tolkanvändning inom akutsjukvård (studie II).

En kvalitativ ansats har använts för att undersöka och beskriva vårdpersonals erfarenheter. Ett ändamålsenligt urval har använts och 79 vårdpersonal på olika nivåer inom respektive organisation deltog, 21 undersköterskor, 26 sjuksköterskor, 1 fysioterapeut, 2 arbetsterapeuter, 1 kurator, 6 läkare och 12 chefer. Datainsamlingen bestod av 44 individuella intervjuer och 9 fokusgrupps intervjuer. En semistrukturerad intervjuguide användes med öppna frågor kring erfarenheter av riktlinjer, samt varför, när och hur tolkanvändning sker. Intervjuerna transkriberades och utskriven text analyserades med en kvalitativ induktiv innehållsanalys.

Resultaten visade att processerna och strukturerna kring tolkservice är komplexa och huvudsakligen kopplade till institutionella, individuella och interpersonella nivåer. På institutionell nivå var den enda formella policy som användes, lagen om offentlig upphandling, en policy för var och hur man beställer professionell tolk. Olika typer av tolkar användes och tolkningspraktiken strukturerades av informella arbetsplatsrutiner självständigt utformade av de professionella grupperna på individ och interpersonell nivå. Den norm och de rutiner som användes bestämdes utifrån tillgång till tolk, tidsaspekter, karaktären på vården, hälsoförhållanden och personens hälsoproblem, samt förväntningar och önskemål från vårdtagaren och/eller vårdpersonalen. Vårdpersonal utryckte önskemål om bättre flexibilitet för att få tillgång till professionella tolkar, utbildning om tolkanvändning $\mathrm{i}$ vården för vårdpersonal och tolkar, samt bättre tekniska lösningar och utrustning.

Slutsatsen är att organiseringen och användningen av tolkar inom äldreomsorg och akutsjukvård är förankrade i den organisatoriska miljön inklusive tillgång till policy och riktlinjer och nära anknutna till individers språkliga kompetens, kulturella värderingar och social faktorer. Användningen av professionell tolk baseras på karaktären på vård inom vårdkontexten, tillgång till tolk, och beslutas utifrån personalens uppskattning av personens hälsotillstånd med avsikten att kunna bistå 
med snabb och individbaserad vård grundad i humanistiska värderingar. Det är således viktigt att tänka över och inbegripa organisatoriska strukturer och kulturell kompetens vid utveckling av tolkservice när man utformar formella riktlinjer och klara rutiner anpassade till vårdkontexten för att uppnå person-centrerad och jämlik vård. 


\section{ACKNOWLEDGEMENTS}

Finally, it is time to finish my licentiate studies, and an interesting journey, rich in experiences, has now come to an end. I would like to express my sincere gratitude to all who have supported me in different ways during the work on this thesis.

All the health professionals participating in the studies for giving me time together and for all the experiences you have shared with me. Without your participation, this thesis would not exist. Many thanks to you!

To my main supervisor Katarina Hjelm and my co-supervisor Emina Hadziabdic. Thank you for the support and coaching during my work. You have helped and challenged me, and shared knowledge and experience about methods and theoretical perspectives which has been important for me during my own learning process.

The Department of Social and Welfare Studies the former division of Health, Activity and Care and the present division of Nursing Sciences for support in the process as a doctoral student, and for giving me time and resources that made it possible for me to write this thesis.

To all doctoral students at the Department of Social and Welfare Studies and the Department of Medical and Health Sciences for your support, interesting discussions and challenging questions during our seminars.

To all colleagues at the Department of Social and Welfare Studies who supported me in different ways during the whole journey. Patrik Rytterström, Gerd Röndahl and Johan Lundgren for your curiosity and interest in discussing different aspects from different angles, and your feedback and tips that were feedforward to me. Anna Bredström and Sabine Gruber who gave me new insights into ethnicity and health and friendly support during my work. Helene Eriksson and Lena Nilsson who encouraged me and shared their energy when mine was gone.

I'm very grateful to Dr Alan Crozier, professional translator, for review of the language and to Inger Frisk professional secretary who transcribed the interviews together with me. 
Many thanks to all my friends who have helped me focus on other things during this period, but also to Berne Persliden, Jenny Morries and Eva Nordström who helped me by reading and improving my text.

Finally, I want to express my profound gratitude to my nearest family Bosse, Per and Lisen, Karin and Elis, who have given me many nice gatherings and relaxing moments together, sharing what is really important in life: LOVE. Thank you my darlings!

This study was supported by grants from Vetenskapsrådet (The Swedish Research Council), Sweden, reference number: 521-2013-2533. 


\section{REFERENCES}

Akhavan, S. (2012). Midwives' views on factors that contribute to health care inequalities among immigrants in Sweden: a qualitative study. Int $J$ Equity Health. 11(1), p. 47. doi: 10.1186/1475-9276-11-47

Albin, B., Hjelm, K., Ekberg, J., Elmstahl, S. (2005). Mortality among 723,948 foreign- and native-born Swedes 1970-1999. European Journal of Public Health. 15(5), pp. 511-517. doi:10.1093/eurpub/ckio26

Almqvist, I. (2016). Tolkutbildning i Sverige - ett kritiskt vägval. Tolkoch översättarinstitutet, Stockholm.

Bagchi, AD., Dale, S.,Verbitsky-Savitz, N., Andrecheck, S., Zavotsky, K., Eisenstein, R. (2011). Examining Effectiveness of Medical Interpreters in Emergency Departments for Spanish-Speaking Patients with Limited English Proficiency: Results of a Randomized Controlled Trial. Annals of Emergency Medicine. 57 (3), pp. 248- 256.

doi:10.1016/j.annemergmed.2010.05.032

Bauer, AM., Alegria, M. (2010). Impact of patient language proficiency and interpreter service use on the quality of psychiatric care: a systematic review. Psychiatr. Serv. 61(8), pp. 765-773.

Becker, MC. (2004). Organizational routines; a review of the literature. Industrial and Corporate Change. 13(4), pp. 643-77.

doi:10.1093/icc/dtho26

Becker, MC., Lazaric, N., Nelson, R., Winter, S. (2005). Applying organizational routines in understanding organizational changes. Industrial and Corporate Change. 14 (5), pp. 775-791 doi:10.1093/icc/dtho71

Bernstein, J., Bernstein, E., Dave, A., Hardt, E., James, T., Linden, J., Mitchell, P,. Oishi, T., Safi, C. (2002). Trained medical interpreters in the emergency department: Effects on services, subsequent charges, and follow-up. Journal of Immigrant Health. 4(4), pp. 171-176. 
Bischoff, A. (2003). Caring for migrant and minority patients in European hospitals: A review of effective interventions. Institute for the Sociology of Health and Medicine. Vienna.

Bischoff, A. \&Hudelson, P. (2010). Communicating with foreign languagespeaking patients: Is access to professional interpreters enough? Journal of Travel Medicine. 17, pp. 15-20. doi: 10.1111/j.1708-8305.2009.00314.x

Brämberg, E.B. \& Sandman, L. (2013).Communication through in-person interpreters: a qualitative study of home care providers' and social workers' views. Journal of clinical nursing. 22.(1-2), pp. 159-167. doi:10.1111/j.1365-2702.2012.04312.x04312.

Bredström, A. \& Gruber, S. (2015). Language, Culture and Maternity Care: "Troubling” Interpretation in an Institutional Context. Nordic Journal of Migration Research. 5(2), pp. 58-66. doi:10.1515/njmr-20150010

Brenner, E., Rydell, P., Skoog, I. (red.) (2016) Akut psykiatri .2 ed. Studentlitteratur. Lund.

Brisset, C., Lenaza, Y., Laforest, K. (2013). Working with interpreters in health care: Asystematic review and meta-ethnography of qualitative studies. Patient Education and Counseling 91, pp. 131-140.

doi:10.1016/j.pec.2012.11.008

Bülow, P., Persson Thunqvist, D., Sandén, I. (2012). Kommunikation som praktik. En teoretisk bakgrund I Persson Thunqvist, D. Sandén, I. Bülow, P., (ed.) Delaktighetens praktik. Det professionella samtalets villkor och Möjligheter: Malmö, Gleerups.

Butow, PN., Lobb, E., Goldsteing, D., Eisenbruch, M., Girgis, A., King, M., Sze, M., Aldridge, L., Schrofiels, P. (2012). A bridge between cultures: interpreter's perspective of consultations with migrant oncology patients. Supportive Care in Cancer. 20 (2), pp. 235-244. doi: 10.1007/so0520010-1046-Z

Delisle, J. \& Woodsworth, J. (2012). Translators through History. Benjamins Translation Library 101. Rev. (ed), pp. 337. J Benjamin Publishing Company Amsterdam. doi:10.1075/btl.101. 
Engstrand, Å.-K. \& Karlsson, J. (2013). Intersektionalitet - att fånga ojämlikhetens komplexitet på flera sätt. In Dahlstedt, M. \& Neergaard, A. (ed.)Migrationens och etnicitetens epok: Kritiska perspektiv $i$ etnicitetsoch migrationsstudier. Malmö, Liber.

Divi, C., Koss, R., Schmaltz, S., Loeb, J.(2007). Language proficiency and adverse events in US hospitals: a pilot study. Int $J$ Qual Health Care. 19(2), pp. 60-67.

Edwards, R., Temple, B., Alexander, C. (2005). Users' experiences of interpreters; the critical role of trust. Interpreting. (7), pp. 77-95.

Fatahi, N., Hellström, M., Skott, C., Mattsson, B. (2008). General practitioners' views on consultations with interpreters: A triad situation with complex issues. Scandinavian Journal of Primary Health Care. 26(1), pp. 40-45.

Fatahi, N., Nordholm L., Matsson, B., Hellström, M. (2010 a). Experiences of Kurdish war-wounded refugees in communication with Swedish authorities through interpreter. Patient Education and Counselling, 78 (2), pp. 160-165

Fatahi, N., Mattsson, B., Lundgren, SM., Hellström, M. (2010 b). Nurse radiographers' experiences of communication with patients who do not speak the native language. Journal of Advanced Nursing. 66(4), pp. 774783.

Feldman, S M. (2000). Organizational Routines as a Source of Continuous Change. Organization Science 11, pp. 611-629.

Flores, G. (2005). The impact of medical interpreter services on the quality of health care: a systematic review. Med Care Res Rev. 62(3), pp. 255-299. doi:10,1177/1077558705275416.

Förvaltningslag.1986:223. (Management Act) Stockholm: Justitiedepartementet http://www.riksdagen.se/sv/Dokument [18 June 2017] 
Gerrish, K. \& Clayton, J. (2004). Bridging the language barrier: the use of interpreters in primary care nursing. Health and Social Care in the Community. 12 (5), pp. 407-431.

Ginde, AA. Clark, S., Camargo Jr, CA. (2009). Language Barriers among Patients in Boston Emergency Departments: Use of Medical Interpreters After Passage of Interpreter Legislation. J Immigr Minor Health. 11(6), pp. 527-530. doi: 10.1007/s10903-008-9188-5.

Ginde, AA., Sullivan, AF., Corel, B., Caceres, JA., Camargo Jr, CA.( 2010). Reevaluation of the effect of mandatory interpreter legislation on use of professional interpreters for ED patients with language barriers. Patient Educ Couns. 81(2), pp. 204-6. doi:10.1016/j.pec.2010.01.023,

Greenhalgh, T., Voisey, C., Robb, N. (2007). Interpreted consultations as 'business as usual'? An analysis of organisational routines in general practices. Sociol Health Illn. 29(6), pp. 931-954. doi: 10.1111/j.1467 9566.2007.01047.x

Greenhalgh, T. (2008). Role of routines in collaborative work in healthcare organisations. BMJ. 337, pp. 1269-1271.

doi: 10.1136/bmj.a2448

Gunnarsson, Britt-Louise. (2014). Multilingualism in European workplaces. Multilingua 33(1-2), pp. 11-33. doi:10.1515/multi-20140002

Institutionen för språk och folkminnen. (2017). Minoritetsspråk. http://www.sprakochfolkminnen.se/sprak/minoritetssprak.html [29 March 2017]

IOM. International organization for migration. (2017). World migration report 2018. https://www.iom.int/wmr/world-migration-report-2018 [11 December 2017]

Janson, G. \& Wadensjö, C. (2014). Care identitites and interpreting practices. In Kahlin, L., Landqvist, M., Tykesson. (ed.) Språk och identitet: rapport från ASLA:s. symposium, Södertörns högskola 8-9 maj 2014. Huddinge, pp. 59-75. 
Jacobs, E.A., Leos, G.S., Rathouz, P.J., Fu, Jr P. (2011). Shared Networks of Interpreter Services, at Relatively Low Cost, Can Help Providers Serve Patients with Limited English Skills. Health Affairs. 30(10), pp. 1930-38. doi:10.1377/hlthaff.2011.0667.

Hadziabdic, E., Heikkilä, K., Albin, B., Hjelm, K. (2009). Migrants' perceptions of using interpreters in health care. International Nursing Review. 56(4), pp. 461-469. doi:10.1111/j.1466-7657.2009.00738.x

Hadziabdic, E., Albin, B., Heikkilä, K., Hjelm, K. (2010).Healthcare staffs perceptions of using interpreters: a qualitative study. Primary Health Care Research \& Development. 1(1), pp. 1-11. doi:10.1017/S146342361000006X

Hadziabdic, E., Heikkila, K., Albin, B., Hjelm K. (2011). Problems and consequences in the use of professional interpreters: qualitative analysis of incidents from primary healthcare. Nurs Inq. 18 (3), pp. 253-261. doi:10.1111/j.1440-1800.2011.00542.x

Hadziabdic, E. \& Hjelm, K. (2013). Working with interpreters: practical advice for use of an interpreter in healthcare. Int J Evid Based Health 11, pp. 69-76. doi:10.1111/1744-1609.12005

Hadziabdic, E., Albin, B., Heikkila, K., Hjelm, K. (2014). Family members' experiences of the use of interpreters in healthcare. Prim. Health Care Res Dev. 15(2), pp. 156-69. doi: 10.1017/S1463423612000680

Hadziabdic, E. \& Hjelm, K. (2014). Arabic-speaking migrants experiences of the use on interpreters in healthcare: a qualitative explorative study. Int. Journal for Equity in Health. 13(1), pp. 49. doi: 10.1186/1475-927613-49

Hadziabdic, E \& Hjelm, K. (2016). Perspectives of professional interpreters regarding their role and attitude in the healthcare encounter. Diversity and Equality in Health and Care 13(3),pp. 221-229.

Hampers, L., Cha, S., Gutglass, D.J., Binnis, H.J. Krug, S.H. (1999). Language barriers and resource utilization in a pediatric emergency department. Pediatrics, 103, pp. 1253-1256. 
Hsieh, E. (2008). "I am not a robot!" Interpreters' views of their roles in health care settings. Qual Health Res, 18, pp. 1367-83.

Hishe, E. \& Hong, S.J. (2010). Interpreters in Health Care: Not all are desired: Providers' views on interpreters' emotional support for patients. Patient Educ Couns. 81(2), pp. 192-197. doi:10.1016/j.pec.2010.04.004.

Hsieh, E. \& Kramer, E. M.(2012). Medical interpreters as tools: dangers and challenges in the utilitarian approach to interpreters' roles and functions. Patient Educ Couns, 89, pp. 158-62.

Hsieh, E. (2015).Not just “Getting by": Factors Influencing Providers Choice of Interpreters. I Gen Intern Med. 30(1), pp. 75-85. doi:10.1007/s116060143066-0.

Kale, E. \& Syed, HR. (2010). Language barriers and the use of interpreters in the public health services. A questionnaire-based survey. Patient Educ Couns. 81(2), pp. 187-91. doi:10.1016/j.pec.2010.05.002.

Kammarkollegiet. (2017). Kammarkollegitets tolkföreskrifter https://www.kammarkollegiet.se/tolkar-och-oversattare/omauktorisation-tolkar-och-oversattare-rattssakerhet. [18 June 2017]

Kammarkollegiet. (2017). God tolksed: Vägledning för auktoriserade tolkar. (Legal, Financial and Administrative Services Agency in Sweden) https://kammarkollegiet.se/search?s=god+tolksed [18 June 2017]

Karliner, L., Jacobs, E., Chen, A., Mutha, S. (2007). Do professional interpreters improve clinical care for patients with limited English proficiency? A systematic review of the literature. Health Serv Res. 42(2), pp. 727-54. .doi:10.1111/j.1475-6773.2006.00629.x.

Karliner, L., Hwang, S., Nickleach, D., Kaplan, C. (2011). Language barriers and patient-centered breast cancer care. Patients Educ. Couns. 84(2), pp. 223-228. doi:10.1016/j.pec.2010.07.009

Kirmayer, L J. (2011). Multicultural medicine and the politics of recognition. $J$ Med Philos. 36(4), pp. 410-423.

Krippendorff, K. (2004). Content Analysis. An Introduction to Its Methodology. London, SAGE Publications. 
Krueger, RA., Casey, MA. (2015). Focus groups: A practical guide for

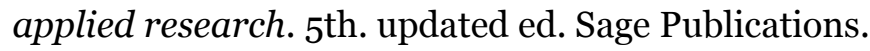

Krupic, F., Hellström, M., Bisevic, M., Sadic, S., Fatahi, N. (2016). Difficulties in using interpreters in clinical encounters as experienced by immigrants living in Sweden. Journal of Clinical Nursing . 25(11-12), pp. 1721-1728. doi: 10.1111/jocn.1322

Krupic, F., Samuelsson, K., Fatahi, N,. Skoldenbergs, O., Sayed-Noor, A. (2017). Migrant General Practitioners' Experiences of Using Interpreters in Health-care: a Qualitative Explorative Study. Med Arch. 71(1), pp. 4247. doi: 10.5455/medarh.2017.71.42-47.

Lag om etikprövning av forskning som avser människor (2003;460) (Swedish law; Regulation of ethical research involving humans). http://www.riksdagen.se/sv/dokument-lagar/dokument/svensk författningssamling/lag-2003460-om-etikprovning-av-forskning som sfs2003-46o [8 June 2017]

Liu, CH., Meeuwesen, L. van Wesel, F,. Ingelby, D. (2015). Why do ethnic Chinese in the Netherlands underutilize mental health care services? Evidence from a qualitative study. Transcultural Psychiatry. 52(3), pp. 331-352.

Leanza, Y. (2005). Roles of community interpreters as seen by interpreters, physicians, and researchers. Interpreting, 7, pp. 167-92.

Leanza, Y., Boivin, I., Rosenberg, E. (2010). Interruptions and resistance: A comparison of medical consultations with family and trained interpreters. Social Science \& Medicine 70 (12), pp. 1888-1895. doi: 10.1016/j.socscimed.2010.02.036.

Leininger, MM., McFarland, MR. (2006). Culture care diversity and universality: a worldwide nursing theory. 2nd ed. London: Jones and Bartlett.

Lill, L. (2007). Att göra etnicitet inom äldreomsorgen. (Doing ethnicity in elderly care). Diss. Internationell Migration och Etniska Relationer (IMER): Malmö Högskola. 
Linell, P. (1990). De institutionaliserade samtalens elementära former; om möten mellan professionella och lekmän. Forskning om utbildning. 17, pp. 18-35. https://ipkl.gu.se/kontakt/personal/per.linell/downloads.

Linell, P. (2011). Samtalskulturer: Kommunikativa verksamhetstyper $i$ samhället. Linköping University: Studies in Language and Culture No. 18, Liu Tryck, Sweden.

Linell, P. (2012). On the Nature of Language: Formal Written-LanguageBiased Linguistics vs. Dialogical Language Sciences. In Kravchenko, A. (ed.) Cognitive Dynamics in Linguistic Interactions, Newcastle upon Tyne. Cambridge Scholars Publishing, pp. 107-124.

MacFarlane, A., Dzebisova, Z., Karapish, D., Kovacevic, B., Ogbebor, F., Okonkowo, E. (2009). Arranging and negotiating the use of informal interpreters in general practice consultations: Experiences of refugee and asylum seekers in the west of Ireland. Social Science \& Medicine. 69 (2), pp. 210-214.

Mahmoud, I., Hou,. X, Chu, K., Clark, M. (2013). Language affects length of stay in emergency departments in Queensland Public Hospital. World $J$ Emer. Med. 4(1), pp. 5-9. doi: 10.5847/wjem.j.1920-8642.2013.01.001

McDowell, L., Messias, DKH., Estrada, RD. (2011). The work of language interpretation in health care: Complex, challenging, exhausting, and often invisible. Journal of Transcultural Nursing, 22(2), pp. 137-147. doi:10.1177/1043659610395773

Messias, DKH., McDowell, L., Estrada, RD. (2009). Language interpreting as social justice work: perspectives of formal and informal healthcare interpreters. Advances in nursing science. 32(2), pp. 128-143.

Ministry of Health and Social Affairs (2009) Värdigt liv i äldreomsorg (Socialdepartementet Regeringens proposition 2009/10: 116). Stockholm: Regeringskansliet [15 December 2016]

MYH. Swedish National Agency for Higher Vocational Education (2015). Översyn kontakttolk slutrapport. Myndigheten för yrkeshögskolan. https://www.myh.se/Global/Blitolk/Regeringsuppdrag-RAPPORT2015.pdf [8 June 2017] 
Niska, H. (2007). From helpers to professionals Training of community interpreters in Sweden. In Wadensjö, C. Englund-Dimotrova, B. Nilsson, A.-L. (ed.) Benjamins Translation Library. 70 Critical Link 4:

Professional of interpreting in the community. $\mathrm{J}$ Benjamin Publishing Company. Amsterdam, pp. 297-314. doi:10.1075/btl.70.32nis.

Njeru, JW. Sauver, JL., Jacobson, D., Ebbert, J., Takashi, PY., Fan C, Wieland, ML. (2015). Emergency department and inpatient health care utilization among patients who require interpreter services. BMC Health Services Research. 29 (15), pp. 214. doi: 10.1186/s12913-015-0874.

Patton, MQ. (2015). Qualitative Research \& Evaluation Methods. 4th ed. London: Sage Publications.

Ramirez, D., Engel, KG., Tang, TS. (2008).Language interpreter utilization in the emergency department setting: a clinical review. $J$ Health Care Poor Underserved. 19(2), pp. 352-362. 10.1353/hpu.o.oo19.

Ramsey, KW., Davis, J., French, G. (2012). Perspectives of Chuukese patients and their health care providers on the use of different sources of interpreters. Hawaï journal of medicine \& public health: a journal of Asia Pacific Medicine \& Public Health. 71(9), pp. 249-252.

Ray, MA., Turkel, MC. (2015). Marilyn Anne Ray's Theory of Bureaucratic Caring. In Nursing Theories and Nursing Practice, ed. by MC, Smith \& ME, Parker. 4 ed. Philadelphia: F.A. Davis Company

Ray, MA. (2016). Transcultural caring dynamics in nursing and health care. 2 ed. Philadelphia: F.A. Davis Company.

Reilly, MJ. \& Markenson, DS. (2010). Health care emergency management; Principles and Practice. Jones and Bartlett Learning. USA.

Rosenberg, E., Seller, R., Leanza, Y. (2008). Through interpreters' eyes: comparing roles of professional and family interpreters. Patient Educ Couns. 70(1), pp. 87-93.

Schatzki, T. (2012). A primer on practices. In J. Higgs, R. Barnett, S. Billet, M. Hutchings, \& F. Trede (ed.), Practice based education, pp. 1326. Rotterdam: Sense Publishers. 
Schenker, Y., Pérez-Stable, E., Nickleach, D., Karliner, L. (2011). Patterns of Interpreter Use for Hospitalized Patients with Limited English Proficiency. J Gen Intern Med. 26(7), pp. 712-7 doi: 10.1007/s11606-010 1619-z.

SCB, Statistiska Centralbyrån. (2016) Utrikesfödda efter län, kommun och födelseland december 2016. (Statistics Sweden) http://www.scb.se Örebro; Statistiska centralbyrån. [15 December 2016]

Seffo, N., Krupic, F., Grbic, K., Fatahi, N. (2014). From Immigrant to Patient: Experiences of Bosnian Immigrants in the Swedish Healthcare System. Materia Socio-Medica 26(2), pp. 85-89, doi:105455/msm.

SFS. 1985:613. Förordning om auktorisation av tolkar och översättare (The Swedish National Courts Administration). Stockholm: Justitiedepartementet http://www.riksdagen.se/sv/Dokument [18 June 2017]

SFS. 2016:1145. Lag om offentlig upphandling (Public Procurement Act) Stockholm: Justitiedepartementet http://www.riksdagen.se/sv/Dokument [18 June 2017]

SFS. 2014:821. Patient lag (The Swedish Patient Act) Stockholm: Justitiedepartementet:http://www.riksdagen.se/sv/Dokument [18 June 2017]

SFS: 2017:30. Hälso- och sjukvårdslagen (The Swedish Health and Medical Services Act). Stockholm: Justitiedepartementet http://www.riksdagen.se/sv/Dokument [18 June 2017]

SFS 2001:453. Socialtjänstlagen (The Social Services Act). Stockholm: Justitiedepartementet http://www.riksdagen.se/sv/Dokument [18 June 2017]

SFS. 2003:460. Ethical considerations of research involving humans Stockholm: Justitiedepartementet http://www.riksdagen.se/sv/Dokument [18 June 2017]

Smith, MK. (1994). Local Education: Community, Conversation, Praxis. UK, Buckingham: Open University Press. 
SNBHW. (2015). Äldreomsorg på minoritetsspråk (Swedish National Board of Health and Welfare, SNBHW).

https://www.socialstyrelsen.se/publikationer2015/2015-10-15

Stockholm. [15 December 2016]

SNBHW. (2016 a). Vård och omsorg om äldre, En lägesrapport 2016 https://www.socialstyrelsen.se/publikationer2016/2016-2-29 [15 October 2017]

SNBHW. (2016 b). Nationella riktlinjer för vård och omsorg vid demenssjukdom: Stöd för styrning och ledning (National guidelines for health care in dementia Support for governance and management) http://www.socialstyrelsen.se/publikationer2016/2016-11-7 Stockholm: [25 April 2017]

SNBHW. (2016 c) Tolkar för hälso- och sjukvården och tandvården Stockholm https//:www.socialstyrelsen.se/publikationer2016/[7 May 2016]

SOU (2017). Läs mig! Nationell Kvalitets plan för vård och omsorg om äldre personer (Official Reports of the Swedish Government) (2017:21, del 1). Stockholm: Socialdepartementet [20 August 2017]

Syse, A., Strand, B., Naess, O., Steingrimsdottir, OA., Kumar, B. (2016). Differences in all-cause mortality: A comparison between immigrants and the host population in Norway 1990-2012. Demographic Research. 34(22), pp. 615-656. doi:10.4054/DemRes 2016.34.22

Szebehely, M. \& Trydegård, G-B. (2012). Home care for older people in Sweden: a universal model in transition. Health and Social Care in the Community 20(3), pp. 300-309. doi: 10.1111/j.1365-2524.2011.01046.x

Turkel, MC. (2007) Dr. Marilyn Ray's Theory of Bureaucratic Caring. International Journal for Human Caring 11(4), pp. 57-74.

Wallace, M. \& Kulu, H. (2014). Low immigrant mortality in England and Wales: A data artefact? Social Science and Medicine. 120, pp. 100-109. doi:10.1016/j.soc scimed.2014.08.032. 
Ventriglio, A., Baldessarini, RJ., Iuso, S., La Torre, A., D’Onghia A., La Salandra M., Mazza M., Bellomo A. (2013). IJSP o(o), pp. 1-5. doi: 10.1177/0020764013487653

Vissandjée, B., Short, W.E., Bates, K. (2017). Health and legal literacy for migrants: twinned strands woven in the cloth of social justice and the human right to health care. BMC Int Health \& Human Rights 17 (10). doi 10.1186/s 12914-017-0117-3

WHO. World Health Organization. (2008). Human rights, health and poverty reduction strategies: World Health Organization http://www.who.int/hdp/publications/human_rights.pdf [2 October 2017]

WMA. World Medical Association. (2013). Declaration of Helsinki: Ethical Principles for Medical Research Involving Human Subjects. https://www.wma.net/policies-post/wma-declaration-of-helsinki-ethicalprinciples-for-medical-research-involving-human-subjects/ [9 October 2017]

Zenderdel, R., Schouen, B., van Weert, J., van den Outte, B. (2018). Informal interpreting in general practice; the migrant patient's voice. Ethnicity \& Health. 23(2), pp. 158-173. http://dx.doi.org/10.1080/13557858.2016.1246939 


\section{Papers}

The papers associated with this thesis have been removed for copyright reasons. For more details about these see:

http://urn.kb.se/resolve?urn=urn:nbn:se:liu:diva-145228 